\title{
屋外彫刻設置事業プロセスからみた設置空間の景観特性に関する研究 LANDSCAPE CHARACTERISTICS OF INSTALLATION SPACE FROM THE OPEN-AIR SCULPTURE INSTALLATION PROJECT PROCESS
}

\author{
山本有希子*，鵤 心治** \\ Yukiko YAMAMOTO and Shinji IKARUGA
}

\begin{abstract}
Open-air-sculpture is one of the elements which constitute an urban landscape. However, when sculpture is installed, neither the index by which they are evaluated, nor the standard to install exists. We think it important to clarify relation between sculpture, urban space, and an observer from a visual point of a landscape. The purpose of this research is to clarify the technique of installing sculpture in urban space from the visual relation of a landscape.

The conclusion is as follows;

1. The difference in the process of a project of installing sculpture affects the feature of a landscape.

2. About the urban space in which sculpture is installed, the subject with which a sculptural producer intention and the concept of an urban design disagree occurs.

3. When the purpose of a project is community design, a sense of unity and originality are produced, and when it is landscaping, making a excursion and stopping at view point are produced in urban space.
\end{abstract}

Keywords: Urban Space, Landscape Design, Open-Air Sculpture, Project Process, Landscape Structure 都市空間，景観デザイン，屋外彫刻，事業手法，景観構造

\section{1. 研究の背景と目的}

2004 年の景観法施行により、良好な景観は「国民共通の資産」(第 2 条第 1 項)であり、「地域の自然、歴史、文化等と人々の生活、経済 活動等との調和により形成される」(第 2 条第 2 項) と規定され、各自 治体は、独自性や地域性を盛り込夕ながら景観施策を実施している。

一方 1960 年代から、都市景観の修景を目的として街中への屋外彫 刻注1)の設置が始められ、現在では多くの自治体で取り組まれるよう になった。このような事業の源と言われている ${ }^{1)}$ 山口県宇部市では、 現在、市街地内公共空間に多くの彫刻が設置され、一般的市街地の修 景と文化振興、地域の個性を表出させる事業として認知され、全国的 に普及寸ることにつながった。筆者らは、この点で、屋外彫刻設置事 業は景観法の理念を推進する具体的な示唆を内在していると考えて いる。

このような屋外彫刻に関する既往研究として、まず国内では、日 本における彫刻設置事業について、その経緯、目的、彫刻自体の特 徵、選定、普及啓発手法を整理した竹田ら ${ }^{1)}$ ５) の一連の研究がある。 また、都市空間と彫刻の関係を取り上げた研究としては、小林ら ${ }^{6)}$ 、 7)の彫刻が置かれた公共空間の質を定性的、歴史的に整理した研究 や、志水ら ${ }^{8)}$ 11) の屋外彫刻が都市空間に及ぼす心理的影響について 画像を用いて評価実験をおこなった研究、上本ら 12)、13)の住民参加 による作品設置を調査した研究がある。更に、立川市で実現したフ アーレ立川に関する事業経緯とその手法について木村ら ${ }^{14)}$ が報告
を行っている。

国外では、M・A・ロビネット ${ }^{15)}$ による屋外彫刻の意義と機能、設置 環境の種類、評価語彙、住民意向などを定性的に分析した研究があ り、屋外彫刻の選定や設置の評価指針となりえる原則や評価基準は 存在せず、客観的な評価の重要性を指摘している。

以上のように、彫刻設置のための評価指標や設置基準を明確に論 じた研究は少なく、彫刻・都市空間・見る人の関係を視覚的な特徵 として視点場と視対象という景観の基本的構成に立って論じた研究 は非常に少ない。

そこで本研究では、屋外彫刻設置事業の背景やプロセスからみた 屋外彫刻設置空間の視覚的景観特性を明らかにした上で、彫刻を市 街地内に設置する際の知見を得ることを目的としている ${ }^{16) ~ 20) 。 ~}$

\section{2. 研究の方法}

まず、全国で実施されている屋外彫刻設置事業に関するアンケー 卜調查を行い、日本における屋外彫刻設置事業の現状を整理すると 共に、その特徴を明らかにする。

次に、アンケート結果をもとに、数量化而類分析により屋外彫刻 設置事業の傾向を分析した上で、クラスター分析を用いて事業手法 の違いによる事業プロセスタイプの分類を行う。

最後に、各事業プロセスタイプの傾向を代表する都市を選出して 現地調査を行い、景観の基本的構成について分析を行う。

\footnotetext{
*侏アール・アイ・エー 工修

** 山口大学大学院理工学研究科 教授・工博 
以上の方法により得られたデータを基に、彫刻設置プロセスと設 置空間との関倸性について考察を行う事で、彫刻を既成市街地内に 設置する際の知見を得る。

\section{3. 全国の屋外彫刻設置事業の特徵}

全国で実施されている屋外彫刻設置事業の現状を整理し、その特 徵を明らかにするため、文献調查とヒアリング調查により、屋外彫 刻設置事業の実施が確認できた 170 の自治体を対象にアンケート調 查を行った。105 自治体から回答があり、回収率は $61.8 \%$ であった。 アンケート内容は、事業の現状と設置された屋外彫刻の現状に関す るものである(図 1)。

ここでは、屋外彫刻の設置プロセスと、設置空間および、設置場 所の決定理由に着目して集計し、特徴がみられた項目について整理、 考察を行った。

\section{1 事業の継続性に関する特徵}

事業の継続性は、事業終了年度が未決定の事業を「継続的」な事 業、事業終了年度が決定済みの事業を「継続的ではない」事業と定 義し、集計を行った。その結果、「継続的ではない」事業が 43 件と なっており、「継続的」な事業よりも多いという事が分かった (表 1)。 まず、「継続的」な事業の場合、「設置場所の考慮」については、 「設置場所を決定せずに彫刻を制作・設置」している場合が 15 件 $(55.6 \%)$ と最も多くなっており、「設置場所決定範囲」は「市・区内 の公共施設敷地内、街区、公共施設」が 7 件 (25.9\%) と最も多くな っている（表 1、表 2）。また、「データベースの有無」に関しては、 「ある」場合が 18 件 (66.7\%) と最も多くなっている（表 3)。

一方、「継続的ではない」事業の場合、「設置場所の考慮」につい ては、「予め設置場所を決定し、その場所性を考慮した彫刻を制作・ 設置」している場合が 18 件 (41.9\%) と最も多くなっている(表 1)。 また、「設置場所決定範囲」は「特定の公園・敷地内、区間」が 12 件 (27.9\%) と最も多くなっている(表 2)。しかし、「データベースの 有無」に関しては、「ない」場合が 22 件 $(53.7 \%)$ と最も多くなって いる（表 3)。

\section{2 設置場所の決定理由に関する特徵}

設置場所の決定理由の中で最も多かったのは、「まちの玄関口、シ ンボルとなるところ」で、13 件である(表 4)。

まず、「作品と周辺環境の適合性（景観）」を理由として設置場所 を決定している事業の場合、「事業継続年数」は「6〜10 年間」が 5 件 (50.0\%) と最も多くなっている(表 4)。また、「彫刻設置数」に関 しては、「1〜20 基」、「21〜 40 基」の場合が 3 件 (30.0\%) と最も多く なっている（表 5)。

一方、「安全性、広さ・経済的に可能かどうか」を理由とした事業 の場合、「事業継続年数」は「1 5 年間」が 5 件 (55.6\%) と最も多 くなっている(表 4)。また、「設置彫刻数」は「41〜60 基」が 6 件 (66.7\%) と最も多くなっている（表 5)。

\section{3 住民意向調査に関する特徵}

住民意向調查は、「ない」場合が 66 件となっており、「ある」場合 よりも多い(表 6)。

住民一の意向調查が「ある」事業の場合、「設置場所決定範囲」は「特 定の場所」が 6 件 (26.1\%) と最も多くなっている(表 6)。また、「設 置場所の考慮」については、「予め設置場所を設定し、その場所の景

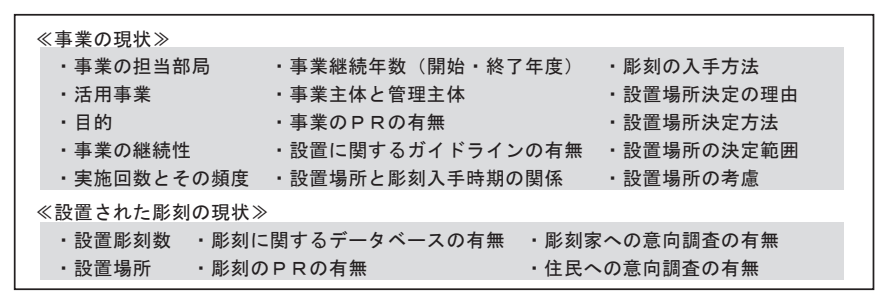

図 1 アンケート内容

表 1 事業の継続性と設置場所の考慮

\begin{tabular}{|c|c|c|c|c|c|c|}
\hline & \begin{tabular}{|l|l} 
予め設置場所 \\
を設定し \\
の場所の景 \\
観・場所性を \\
考虐した彫刻 \\
を制作・設置
\end{tabular} & 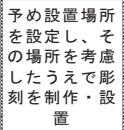 & 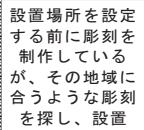 & 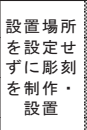 & $\begin{array}{l}\text { 無回答 } \\
\text { 不明 }\end{array}$ & 合計 \\
\hline \multirow{2}{*}{ 継続的 } & 3 & 5 & 2 & 15 & 2 & 27 \\
\hline & $11.1 \%$ & $18.5 \%$ & $7.4 \%$ & $55.6 \%$ & $7.4 \%$ & $100.0 \%$ \\
\hline 継絸的ではない & 18 & 7 & 2 & 11 & 5 & 43 \\
\hline \multirow{3}{*}{ 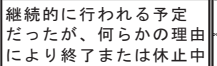 } & $41<9 \times$ & $16.3 \%$ & 4. $7 \%$ & $25.6 \%$ & $11.6 \%$ & $100.0 \%$ \\
\hline & 9 & 4 & 0 & 8 & 0 & 21 \\
\hline & $42.9 \%$ & $19.0 \%$ & $0.0 \%$ & $38.1 \%$ & $0.0 \%$ & $100.0 \%$ \\
\hline
\end{tabular}

表 2 事業の継続性と設置場所決定範囲

\begin{tabular}{|c|c|c|c|c|c|c|c|}
\hline & 特定の場所 & $\begin{array}{l}\text { 特定の公 } \\
\text { 園・敷地 } \\
\text { 内、澗 }\end{array}$ & $\begin{array}{l}\text { 市・ 区内の公 } \\
\text { 園敷地内、街 } \\
\text { 角、公共施設 }\end{array}$ & $\begin{array}{c}\text { 市 } \text {. 区内 } \\
\text { 全域 }\end{array}$ & その他 & $\begin{array}{c}\text { 無回答 } \\
\text { 不明 }\end{array}$ & 合計 \\
\hline \multirow{2}{*}{ 継続的 } & 2 & 2 & 7 & 0 & 3 & 13 & 27 \\
\hline & $7.4 \%$ & $7.4 \%$ & $25.9 \%$ & $0.0 \%$ & $11.1 \%$ & $48.1 \%$ & $100.0 \%$ \\
\hline \multirow{2}{*}{ 継続的ではない } & 4 & 12 & 6 & 0 & 0 & 21 & 43 \\
\hline & $9.3 \%$ & $279 \%$ & $14.0 \%$ & $0.0 \%$ & $0.0 \%$ & $48.8 \%$ & $100.0 \%$ \\
\hline \multirow{2}{*}{$\begin{array}{l}\text { 継続的に行われる } \\
\text { 予定だったが、何 } \\
\text { らかの理由により } \\
\text { 終了まは休止中 }\end{array}$} & 6 & 2 & 5 & 1 & 1 & 6 & 21 \\
\hline & $28.6 \%$ & 9. $5 \%$ & $23.8 \%$ & 4. $8 \%$ & 4. $8 \%$ & $28.6 \%$ & $100.0 \%$ \\
\hline
\end{tabular}

表 3 事業の継続性とデータベースの有無

\begin{tabular}{|c|c|c|c|c|}
\hline & ある & ない & $\begin{array}{c}\text { 無回答 } \\
\text { 不明 }\end{array}$ & 合計 \\
\hline \multirow{2}{*}{ 継続的 } & 18 & 9 & 0 & 27 \\
\hline & $66.7 \%$ & $33.3 \%$ & $0.0 \%$ & $100.0 \%$ \\
\hline \multirow{2}{*}{ 継続的ではない } & 19 & 22 & 2 & 41 \\
\hline & $46.3 \%$ & 53.1 & $4.9 \%$ & $104.9 \%$ \\
\hline \multirow{2}{*}{$\begin{array}{l}\text { 継続的に行われる予定だったが、何らかの } \\
\text { 理由により終了または休中中 }\end{array}$} & 17 & 4 & 0 & 21 \\
\hline & $81.0 \%$ & $19.0 \%$ & $0.0 \%$ & 100.0 \\
\hline
\end{tabular}

表 4 設置場所の決定理由と事業継続年数

\begin{tabular}{|c|c|c|c|c|c|c|c|}
\hline & $\begin{array}{l}1 \sim 5 \\
\text { 年間 } \\
\end{array}$ & $\begin{array}{c}6 \sim 10 \\
\text { 年間 } \\
\end{array}$ & $\begin{array}{c}11 \sim 15 \\
\text { 年間 }\end{array}$ & $\begin{array}{c}16 \sim 20 \\
\text { 年間 } \\
\end{array}$ & $\begin{array}{c}\begin{array}{c}21 \text { 年間 } \\
\text { 以上 }\end{array} \\
\end{array}$ & 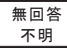 & 合計 \\
\hline \multirow{2}{*}{\begin{tabular}{|l}
$\begin{array}{c}\text { 作品と周辺環境の適合性 } \\
\text { (景観) }\end{array}$ \\
\end{tabular}} & 1 & 5 & 1 & 0 & 0 & 3 & 10 \\
\hline & $10.0 \%$ & $50.0 \%$ & $10.0 \%$ & $0.0 \%$ & $0.0 \%$ & $30.0 \%$ & $100.0 \%$ \\
\hline \multirow{2}{*}{ 彫刻家の意向 } & 1 & 0 & 0 & 0 & 0 & 1 & 2 \\
\hline & $50.0 \%$ & $0.0 \%$ & $0.0 \%$ & $0.0 \%$ & $0.0 \%$ & $50.0 \%$ & $100.0 \%$ \\
\hline \multirow{2}{*}{ 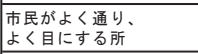 } & 5 & 0 & 1 & 0 & 0 & 2 & 8 \\
\hline & $62.5 \%$ & $0.0 \%$ & $12.5 \%$ & $0.0 \%$ & $0.0 \%$ & $25.0 \%$ & $100.0 \%$ \\
\hline \multirow{2}{*}{ 市民からの要望 } & 1 & 0 & 0 & 0 & 0 & 0 & 1 \\
\hline & $100.0 \%$ & $0.0 \%$ & $0.0 \%$ & $0.0 \%$ & $0.0 \%$ & $0.0 \%$ & $100.0 \%$ \\
\hline \multirow{2}{*}{\begin{tabular}{|l} 
まちの玄関口する \\
シンボルをところ
\end{tabular}} & 4 & 2 & 1 & 3 & 2 & 1 & 13 \\
\hline & $30.8 \%$ & $15.4 \%$ & $7.7 \%$ & $23.1 \%$ & $15.4 \%$ & $7.7 \%$ & $100.0 \%$ \\
\hline \multirow{2}{*}{\begin{tabular}{|l} 
事業計画などのコンセプ \\
トに合っているかどうか
\end{tabular}} & 1 & 1 & 0 & 1 & 1 & 3 & 7 \\
\hline & $14.3 \%$ & $14.3 \%$ & $0.0 \%$ & $14.3 \%$ & $14.3 \%$ & $42.9 \%$ & $100.0 \%$ \\
\hline \multirow{2}{*}{\begin{tabular}{|l} 
安全性、広さ・金銭的に \\
可能かどうか \\
\end{tabular}} & 45 & 1 & 0 & 1 & 2 & 0 & 9 \\
\hline & 556 & $11.1 \%$ & $0.0 \%$ & $11.1 \%$ & $22.2 \%$ & $0.0 \%$ & $100.0 \%$ \\
\hline \multirow{2}{*}{ 公用地であること } & 0 & 0 & 1 & 0 & 0 & 0 & 1 \\
\hline & $0.0 \%$ & $0.0 \%$ & $100.0 \%$ & $0.0 \%$ & $0.0 \%$ & $0.0 \%$ & $100.0 \%$ \\
\hline \multirow{2}{*}{ その他 } & 5 & 3 & 2 & 0 & 0 & 1 & 11 \\
\hline & $45.5 \%$ & $27.3 \%$ & $18.2 \%$ & $0.0 \%$ & $0.0 \%$ & $9.1 \%$ & $100.0 \%$ \\
\hline
\end{tabular}

表 5 設置場所の決定理由と彫刻設置数

\begin{tabular}{|c|c|c|c|c|c|c|c|c|}
\hline & 1 20基 & 21 40基 & $41 \sim 60$ 基 & 61 80基 & $\begin{array}{l}81 \text { 等 } \\
100\end{array}$ & $\begin{array}{l}101 \text { 基 } \\
\text { 以上 }\end{array}$ & $\begin{array}{l}\text { 無回答 } \\
\text { 明 }\end{array}$ & 合計 \\
\hline \multirow{2}{*}{\begin{tabular}{|l} 
作品と周辺環境の適合性 \\
(景観)
\end{tabular}} & 3 & 3 & 1 & 2 & 0 & 0 & 1 & 10 \\
\hline & $30.0 \%$ & $30.0 \%$ & $10.0 \%$ & $20.0 \%$ & $0.0 \%$ & $0.0 \%$ & $10.0 \%$ & $100.0 \%$ \\
\hline \multirow{2}{*}{ 彫刻家の意向 } & 2 & 0 & 0 & 0 & 0 & 0 & 0 & 2 \\
\hline & $100.0 \%$ & $0.0 \%$ & $0.0 \%$ & $0.0 \%$ & $0.0 \%$ & $0.0 \%$ & $0.0 \%$ & $100.0 \%$ \\
\hline \multirow{2}{*}{\begin{tabular}{|l} 
市民がよく通り、 \\
よく目にすす所
\end{tabular}} & 5 & 3 & 0 & 0 & 0 & 0 & 0 & 8 \\
\hline & $62.5 \%$ & $37.5 \%$ & $0.0 \%$ & $0.0 \%$ & $0.0 \%$ & $0.0 \%$ & $0.0 \%$ & $100.0 \%$ \\
\hline \multirow{2}{*}{ |市民からの要望 } & 0 & 1 & 0 & 0 & 0 & 0 & 0 & 1 \\
\hline & $0.0 \%$ & $100.0 \%$ & $0.0 \%$ & $0.0 \%$ & $0.0 \%$ & $0.0 \%$ & $0.0 \%$ & $100.0 \%$ \\
\hline \multirow{3}{*}{\begin{tabular}{|l|} 
まちの玄関口, \\
シンシボルとなここ \\
事業計画などのコンセプ
\end{tabular}} & 5 & 4 & 2 & 1 & 0 & 0 & 1 & 13 \\
\hline & $38.5 \%$ & $30.8 \%$ & $15.4 \%$ & $7.7 \%$ & $0.0 \%$ & $0.0 \%$ & $7.7 \%$ & $100.0 \%$ \\
\hline & 2 & 2 & 2 & 0 & 0 & 1 & 0 & \\
\hline $\begin{array}{l}\text { 事業計画などのコンセプ } \\
\text { トに合っているかどうか }\end{array}$ & $28.6 \%$ & $28.6 \%$ & $28.6 \%$ & $0.0 \%$ & $0.0 \%$ & $14.3 \%$ & $0.0 \%$ & $100.0 \%$ \\
\hline \multirow{2}{*}{\begin{tabular}{|l} 
安全性、広さ・金銭的に \\
能かどうか・
\end{tabular}} & 0 & 2 & $26 /$ & 0 & 0 & 1 & 0 & 9 \\
\hline & $0.0 \%$ & $22.2 \%$ & 660 & $0.0 \%$ & $0.0 \%$ & $11.1 \%$ & $0.0 \%$ & $100.0 \%$ \\
\hline \multirow{2}{*}{ 公用地であること } & 0 & 1 & 0 & 0 & 0 & 0 & 0 & \\
\hline & $0.0 \%$ & $100.0 \%$ & $0.0 \%$ & $0.0 \%$ & $0.0 \%$ & $0.0 \%$ & $0.0 \%$ & $100.0 \%$ \\
\hline \multirow{2}{*}{ その他 } & 4 & 3 & 1 & 0 & 0 & 3 & 0 & 11 \\
\hline & $36.4 \%$ & $27.3 \%$ & $9.1 \%$ & $0.0 \%$ & $0.0 \%$ & $27.3 \%$ & $0.0 \%$ & $100.0 \%$ \\
\hline
\end{tabular}

観・場所性を考慮した彫刻を制作・設置」している場合が 8 件 $(34.8 \%)$ と最も多く、「彫刻 PR の HP の有無」に関しては、「ある」 場合が 12 件 (52.2\%) と最も多くなっている（表 7、表 8$) 。$ 


\section{4 全国の屋外彫刻設置事業の特徴}

上記 3 つの項目に着目したアンケート集計結果より、現在の屋外 彫刻設置事業には下記の特徴があると考えられる。

（1）本来、彫刻設置を行う場合、彫刻制作前に設置場所を決定し、 場所性を考慮して彫刻を制作する方が望ましいと考えられるが、継 続的に事業を進める場合「予め設置場所を決定し、その場所の景観、 場所性を考慮した彫刻を制作、設置」している事業は 3 件 (11.1\%) と少ない。即ち、事業終了年度を決定せずに事業を開始した場合、 設置場所を最初に設定せずに事業を進めていく場合が多く、その点 において改善した方が良いと考えられる。

（2）一方で、周辺環境（景観）との適合性を考慮して設置場所を決 定している場合、事業継続年数は比較的長く、設置された彫刻の数 は少ない。これは、場所性や周辺環境との適合性を分析する為には 学識者などによる都市計画的検討が必要になるためだと考えられる。 例えば金沢市の場合、設置場所案の決定は実行委員会で行うが、そ の案に対して産官学民からなる「まちなか彫刻設置委員会」により現 地視察等を経て再度検討され、実際に設置する場所を決定するとい う手順を踏む。そのため、時間が必要であり設置場所も稂選される のだと考えられる。

（3）住民意向調查を行っている事業の場合、特定の場所を設置場所 として設定した後、景観や場所性を考慮して彫刻を制作設置してい る場合が多いため、その場所にふさわしい彫刻の設置が可能になっ ていると考えられる。また、彫刻 PR のためのホームページやパンフ レットが作成されていることが多く、地域住民への普及活動も活発 である。従って、住民意向調查を行う事は、良好な設置空間をつく り、普及活動にもつながると考えられる。

\section{4. 彫刻設置事業のタイプの抽出}

\section{1 数量化正類分析による事業傾向分析}

ここでは、屋外彫刻設置事業に関するアンケートで事業内容が明 らかになった 61 事業に対し、主として事業プロセスに着目した 41 変量（表 9）の有無を変数とした数量化亚類分析を適用し、得られ たカテゴリースコアをプロットした(図 2)。

その結果、第 1 因子の正方向には「区・市全体の配置バランス」「ま ちの玄関口、シンボルとなる所」等の設置空間決定の際に “都市デザ イン・コンセプトを重視” する項目が、負方向には「彫刻を制作し た後に設置場所を決定」、「彫刻展を開催」等の設置空間決定の際に “芸術文化性・制作者意向を重視” する項目が大きい值を示してい る(表 9, 図 2)。従って、第 1 因子は【彫刻設置のコンセプト】を表 していると考えられる(図 2)。これは、彫刻設置に関して、制作者 意向と都市デザイン・コンセプトが相反することを意味している。

また、第 2 因子の正方向には、「公用地であること」、「住民意向調 查は無い」等の “行政・内部機関主導” で事業を行う項目が、負方 向には、「彫刻家の意向」、「市民からの要望」等の“関係者の合意形 成を重視”して事業を行う項目が大きい值を示している(表 9, 図 2)。 従って、第 2 因子は【設置空間検討プロセス】を表していると考え られる(図 2)。

\section{2 クラスター分析による事業の分類}

全国の屋外彫刻設置事業の特徵として、事業プロセスの違いから みた自治体間の類似性を考察するため分類を行う。分類手法として
表 6 住民意向調査の有無と設置場所決定範囲

\begin{tabular}{|c|c|c|c|c|c|c|c|}
\hline & 特定の場所 & $\begin{array}{l}\text { 特定の公園 - } \\
\text { 敷地内、区間 }\end{array}$ & $\begin{array}{l}\text { 市・ ・ } \text { 敷地内の公園 } \\
\text { 公共施設 }\end{array}$ & $\begin{array}{c}\text { 市· 区内 } \\
\text { 全域 }\end{array}$ & その他 & $\begin{array}{l}\text { 無回答 } \\
\text { 不明 }\end{array}$ & 合計 \\
\hline \multirow{2}{*}{ ある } & 6 & 0 & 2 & 0 & 4 & 11 & 23 \\
\hline & $26.1 \%$ & $0.0 \%$ & $8.7 \%$ & $0.0 \%$ & $17.4 \%$ & $47.8 \%$ & $100.0 \%$ \\
\hline \multirow{2}{*}{ ない } & 4 & 15 & 13 & 1 & 2 & 31 & 66 \\
\hline & $6.1 \%$ & $22.7 \%$ & $19.7 \%$ & $1.5 \%$ & $3.0 \%$ & $47.0 \%$ & $100.0 \%$ \\
\hline
\end{tabular}

表 7 住民意向調査の有無と設置場所の考慮

\begin{tabular}{|c|c|c|c|c|c|c|}
\hline & $\begin{array}{l}\text { 予め設置場所を } \\
\text { 設定して場 } \\
\text { 所の景観・場 } \\
\text { 性を考慮した彫 } \\
\text { 刻を制作・設置 }\end{array}$ & $\begin{array}{c}\text { 予め設置場所を } \\
\text { 設定して場 } \\
\text { 所を考盧したう } \\
\text { えで彫刻を制 } \\
\text { 作・設置 }\end{array}$ & $\begin{array}{l}\text { 設置場所を設定す } \\
\text { 前に彫刻を制作 } \\
\text { ているが、その } \\
\text { 地域に合うような } \\
\text { 彫刻を探し、設置 }\end{array}$ & $\begin{array}{l}\text { 設置場所を } \\
\text { 設定せずに } \\
\text { 彫刻を制 } \\
\text { 作・設置 }\end{array}$ & $\begin{array}{c}\text { 無回答 } \\
\text { 不明 }\end{array}$ & 合計 \\
\hline \multirow{2}{*}{ ある } & 8 & 6 & 2 & 6 & 1 & 23 \\
\hline & $34.8 \%$ & $26.1 \%$ & $8.7 \%$ & $26.1 \%$ & $4.3 \%$ & $100.0 \%$ \\
\hline \multirow[t]{2}{*}{ ない } & 13 & 10 & 3 & 28 & 12 & 66 \\
\hline & $19.7 \%$ & $15.2 \%$ & $4.5 \%$ & $42.4 \%$ & $18.2 \%$ & $100.0 \%$ \\
\hline
\end{tabular}

表 8 住民意向調查の有無と彫刻 PR の HP の有無

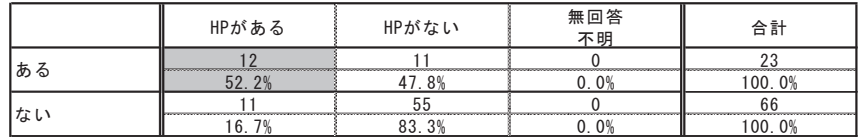

表 9 数量化正類分析に用いた変量

\begin{tabular}{|c|c|c|c|}
\hline \multicolumn{2}{|c|}{ アンケート項目 } & 記号 & 回答肢（カテゴリー名） \\
\hline \multirow{2}{*}{$\begin{array}{c}\text { 都市の } \\
\text { 物理的特徵 }\end{array}$} & \multirow{2}{*}{ C. 景観条例の有無 } & $\mathrm{Ca}$ & ある \\
\hline & & & 無い \\
\hline \multirow{8}{*}{ 事業 } & \multirow{2}{*}{ G. 目的 } & Ga & 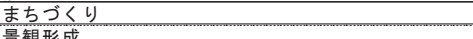 \\
\hline & & Gc & 旻化環境の創造 \\
\hline & \multirow{6}{*}{ H. 入手方法 } & Ha & 寄贈 \\
\hline & & $\mathrm{Hb}$ & 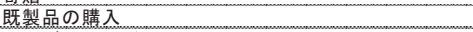 \\
\hline & & $\mathrm{Hc}$ & 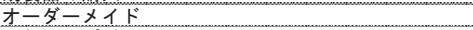 \\
\hline & & Hd & 䂦刻シンホホジム \\
\hline & & $\mathrm{He}$ & 撒刻展 \\
\hline & & $\frac{H+}{\mathrm{la}}$ & コンペ \\
\hline \multirow{23}{*}{ 設置場所 } & \multirow{2}{*}{$\begin{array}{l}\text { I. 設置場所 } \\
\text { 決定時期 }\end{array}$} & $\frac{\mathrm{a} a}{\mathrm{lb}}$ & 郕刻を制作した後 \\
\hline & & $\mathrm{Ic}$ & ケースにより異なる \\
\hline & \multirow{3}{*}{ J ．設置場所の考慮 } & Ja & $\begin{array}{l}\text { 悀め設置場所を設定し、そ盧した㓮刻を制作・設置 } \\
\text { 所の景観・場所性を }\end{array}$ \\
\hline & & $\mathrm{Jb}$ & $\begin{array}{l}\text { 予め設置場所を設定し、その場所を考慮した上で彫 } \\
\text { 制作・設置 }\end{array}$ \\
\hline & & & 設置場所を設定せずに彫刻を制作・設置 \\
\hline & \multirow{5}{*}{$\begin{array}{l}\text { K. 設置場所 } \\
\text { 決定方法 }\end{array}$} & Ka & 彫刻家との現場確認や話し合い \\
\hline & & $\mathrm{Kb}$ & 㡰内で調查・椳討 \\
\hline & & $\mathrm{Kc}$ & 事莱計画畫に基つく \\
\hline & & $\mathrm{Kd}$ & 㖃刻設置のための委員会で調查・検討 \\
\hline & & $\mathrm{Ke}$ & その他 \\
\hline & \multirow{8}{*}{$\begin{array}{l}\text { L. 設置場所 } \\
\text { 決定理由 }\end{array}$} & $\mathrm{La}$ & 作品と周辺環境の適合性 (景観) \\
\hline & & $\mathrm{Lb}$ & 彫刻家の意向 \\
\hline & & Lc & 市民がよく通り、よく目にする所 \\
\hline & & Ld & $\begin{array}{l}\text { 市民からの要望 } \\
\text { まちの糸関口、シンボルとなる所 }\end{array}$ \\
\hline & & $\mathrm{Lf}$ & 事業計画などのコンセプトに合っているかどうか \\
\hline & & $\mathrm{Lg}$ & 区・市全体の配瞋バランス \\
\hline & & $\mathrm{Lh}$ & 安全性、広さ・金鐿的に可能かどうか \\
\hline & & $\mathrm{Li}$ & $\begin{array}{l}\text { 公用地であること } \\
\text { その他 }\end{array}$ \\
\hline & \multirow{5}{*}{ M. 設置場所 } & $\frac{1}{M a}$ & 歩道上 \\
\hline & & $\mathrm{Mb}$ & 歩道沿い(植え込みの中など) \\
\hline & & Mc & 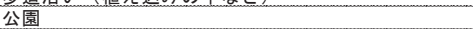 \\
\hline & & Me & 施設㢣地内 \\
\hline & & Mf & その他 \\
\hline \multirow{4}{*}{ 意向調査 } & \multirow{2}{*}{$\begin{array}{l}\text { O. 住民意向調査 } \\
\text { の有無 }\end{array}$} & Oa & ある \\
\hline & & $\mathrm{Ob}$ & 無い \\
\hline & \multirow{2}{*}{$\begin{array}{l}P . \text { 彫刻家意向調査 } \\
\text { の有無 }\end{array}$} & $\mathrm{Pa}$ & ある \\
\hline & & $\mathrm{Pb}$ & \\
\hline
\end{tabular}

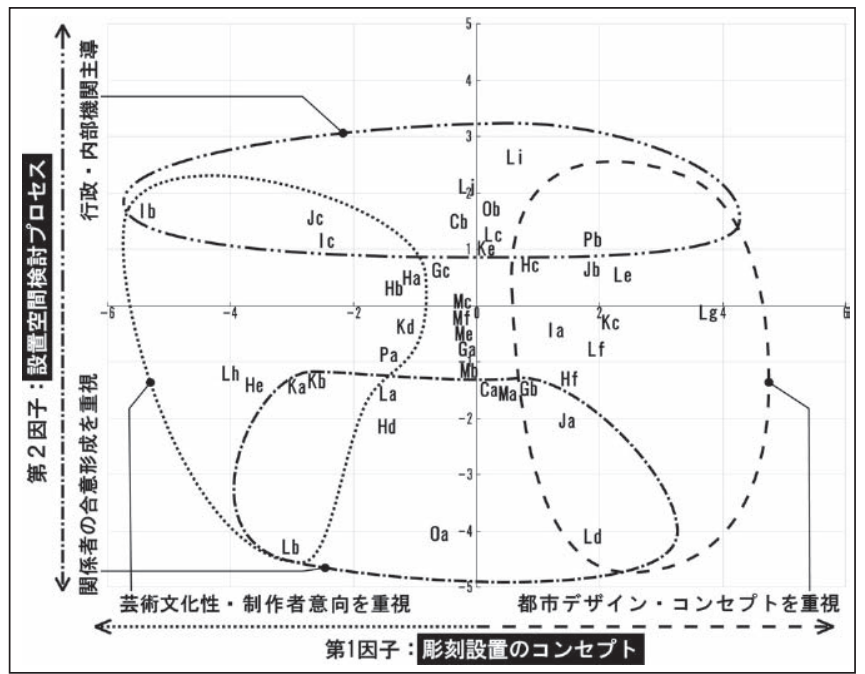

図 2 カテゴリースコア散布図 
は、サンプルスコアーを用いたクラスター分析（ウォード法）を採 用した。

分析の結果、距離 1.2 付近で切り 5 グループとした場合、屋外彫 刻設置事業の先駆けであり事業プロセスがほぼ同じである宇部市と 神戸市が別のグループとなる。事業プロセスの違いによる分類を目 的としているため、この 2 都市を同じグループとした方が良いと判 断し 4 タイプ以下とする事にした。また、距離 1.5 付近で切り 3 グ ループとした場合、現在のタイプ Aとタイプ Bが 1 つのタイプとな ることになるが、この 2 つの゙ループは住民や彫刻家への意向調査 の有無に関して大きく傾向が異なっている。従って、分けた方が良 いと判断し、4タイプに分類することとした(図 3)。

続いて、屋外彫刻設置事業に関するアンケートのタイプ別集計を 行うことで、各タイプの傾向を分析した（表 10〜表 15）。

\section{（1）タイプA：都市デザイン型}

このタイプに属する事業は、X 軸の正方向【都市デザイン・コン セプトを重視】に分布している(図 3)。「目的」は、「まちづくり」 と「景観形成」が 10 件 $(35.7 \%)$ と最も多くなっている(表 10)。ま た、「設置場所決定時期」は、彫刻を「制作する前」が 17 件 (100.0\%) であり、「設置位置が分かる地図の有無」に関しては、「ある」場合 が 14 件 (82.4\%) と最も多くなっている(表 11、表 12)。従って、タイ プA を都市デザイン型とした。

\section{（2）タイプ B：住民合意形成型}

このタイプに属する事業は、X 軸の正方向【都市デザイン・コン セプトを重視】、Y 軸の負方向【関係者の合意形成を重視】に分布し ている (図 3)。「目的」は、「まちづくり」と「景観形成」が 7 件 (36. 8\%) と最も多くなっている(表 10)。また、「設置場所決定時期」は、彫 刻を「制作する前」が 11 件 $(100.0 \%)$ であり、「設置位置が分かる地 図の有無」に関しては、「ある」場合が 11 件 (100.0\%) となっている （表 11、表 12）。さらに、「住民意向調査の有無」は、「ある」場合が 11 件 $(100.0 \%)$ であり、「彫刻家意向調査の有無」は、「ある」場合
が 9 件 $(81.8 \%)$ と最も多くなっている(表 13、表 14)。従って、タイ プ B を住民合意形成型とした。

\section{（3）タイプ C : 行政主導型}

このタイプに属する事業は、Y 軸の正方向【行政・内部機関主導】 に分布している(図 3)。「目的」は、「文化環境の創造」が 12 件 (42.9\%) と最も多くなっている（表 10）。また、「設置位置が分かる地図の有 無」に関しては、「ない場合が 12 件 (52.2\%) と最も多くなっており、 「設置場所決定理由」は「市民がよく通り、よく目にするところ」 が 7 件 (25.9\%) と最も多くなっている (表 12、表 15)。さらに、「住 民意向調査の有無」は、「ない」場合が 21 件 $(91.3 \%)$ と最も多くな っており、「彫刻家意向調査の有無」は、「無い」場合が 13 件 (56.5\%) と最も多くなっている(表 13、表 14)。従って、タイプC を行政主導 型とした。

\section{（4）タイプD：制作者意向重視型}

このタイプに属する事業は、X 軸の負方向【芸術文化性・制作者 意向を重視】に分布している(図 3)。「目的」は、「文化環境の創造」 が 7 件 (43.8\%) と最も多くなっている(表 10)。

また、「設置場所決定時期」は彫刻を「制作した後」が 7 件 (70.0\%) と最も多くなっており、「設置場所決定理由」は、「安全性、広さ・ 金銭的に可能かどうか」が 5 件 $(33.3 \%)$ と最も多くなっている (表 11 、 表 15)。「住民意向調査の有無」は、「ない」場合が 6 件 $(60.0 \%)$ と 最も多くなっており、「彫刻家意向調査の有無」は、「ある」場合が 10 件 (100.0\%) となっている (表 13、表 14)。従って、タイプD を制 作者意向重視型とした。

\begin{tabular}{|c|c|c|c|c|c|c|c|c|}
\hline \multirow{2}{*}{ 回答 } & \multicolumn{2}{|c|}{ A } & \multicolumn{2}{|c|}{ B } & \multicolumn{2}{|c|}{$\mathrm{c}$} & \multicolumn{2}{|c|}{$\mathrm{D}$} \\
\hline & 回答数 & 構成比 & 回答数 & \begin{tabular}{|l|} 
構成比 \\
\end{tabular} & 回答数 & 構成比 & 回答数 & 構成比 \\
\hline まちづくり & 110 & 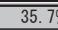 & $\overline{7}$ & $36.8 \%$ & 5 & $\overline{17.9}$ & $\overline{6}$ & $37.5 \%$ \\
\hline 景観形成 & 10 & 35.7 & 7 & $36.8 \%$ & 6 & 21.4 & 2 & $12.5 \%$ \\
\hline 文化環境の創造 & 5 & 17.9 & 4 & $21.1 \%$ & 12 & 42.9 & 7 & $43.8 \%$ \\
\hline その他 & 3 & 10.7 & 1 & $5.3 \%$ & 4 & 14.3 & 1 & $6.3 \%$ \\
\hline 無回答 & 0 & 0.0 & 0 & $0.0 \%$ & 1 & 3.6 & 0 & $0.0 \%$ \\
\hline 合計 & 28 & 100.0 & $\overline{19}$ & $100.0 \%$ & 28 & 100.0 & $\overline{16}$ & 100. \\
\hline
\end{tabular}
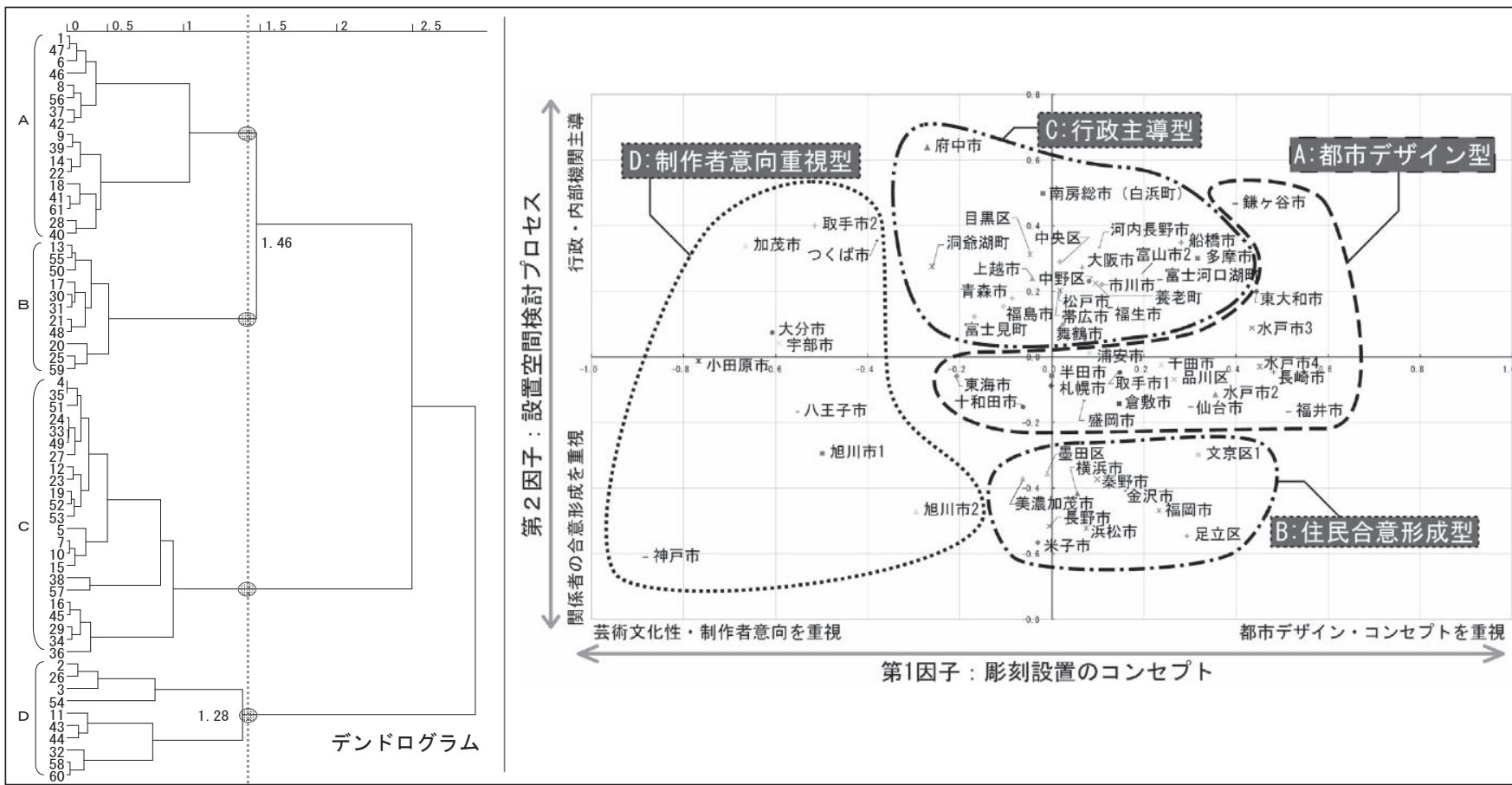

図 3 デンドログラムとサンプルスコアー散布図 
表 11 設置場所決定時期（事業プロセスタイプ別）

\begin{tabular}{|c|c|c|c|c|c|c|c|c|}
\hline \multirow{2}{*}{ 回答 } & \multicolumn{2}{|c|}{$\bar{A}$} & \multicolumn{2}{|c|}{ B } & \multicolumn{2}{|c|}{$C^{2}$} & \multicolumn{2}{|c|}{$D$} \\
\hline & 回答数 & 構成比 & 回答数 & 構成比 & 回答数 & 構成比 & 回答数 & \begin{tabular}{|l|} 
構成比 \\
\end{tabular} \\
\hline 制作する前 & (17] & $100.0 \%$ & $\overline{11}$ & $100.0 \%$ & $\overline{18}$ & 78.39 & $\overline{1}$ & $10.0 \%$ \\
\hline 制作した後 & 0 & $0.0 \%$ & 0 & $0.0 \%$ & 2 & 8.70. & 7 & $70 .(1$ \\
\hline ケースによって異なる & 0 & $0.0 \%$ & 0 & $0.0 \%$ & 3 & 13.0 & 2 & $20.0 \%$ \\
\hline 無回答 & 0 & $0.0 \%$ & 0 & $0.0 \%$ & 0 & 0.0. & 0 & 0.0 \\
\hline
\end{tabular}

表 12 設置位置が分かる地図の有無（事業プロセスタイプ別）

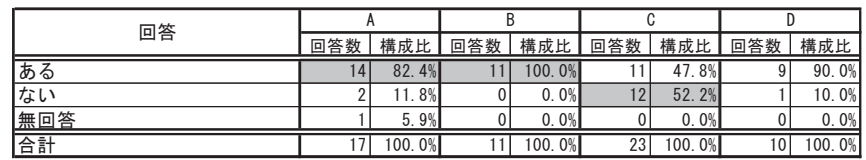

表 13 住民意向調査の有無（事業プロセスタイプ別）

\begin{tabular}{|l|r|r|r|r|r|r|r|r|}
\hline \multirow{2}{*}{ 回答 } & \multicolumn{1}{|c|}{$A$} & \multicolumn{1}{|c|}{ B } & \multicolumn{2}{|c|}{ C } & \multicolumn{2}{|c|}{ D } \\
\cline { 2 - 9 } & 回答数構成比 & 回答数 & 構成比 & 回答数 構成比 & 回答数 構成比 \\
\hline \hline ある & 3 & $17.6 \%$ & 11 & $100.0 \%$ & 0 & $0.0 \%$ & 4 & $40.0 \%$ \\
\hline ない & 10 & $58.8 \%$ & 0 & $0.0 \%$ & 21 & $91.3 \%$ & 6 & $60.0 \%$ \\
\hline 不明·無回答 & 4 & $23.5 \%$ & 0 & $0.0 \%$ & 2 & $8.7 \%$ & 0 & $0.0 \%$ \\
\hline \hline 合計 & 17 & $100.0 \%$ & 11 & $100.0 \%$ & 23 & $100.0 \%$ & 10 & $100.0 \%$ \\
\hline
\end{tabular}

\section{5. 各事業プロセスタイプの設置空間の特徵}

ここでは、各タイプから代表都市を選出し、彫刻設置空間の現地 調査を行い事業プロセスタイプと彫刻設置空間の関係性を考察した。

各タイプの代表都市の選出条件は、(1)事業プロセスタイプ別の屋 外彫刻設置事業に関するアンケート集計結果により明らかになった 各タイプの事業傾向に多く一致していること、(2)事前調査により、 彫刻の設置されている場所を確認できること、(3)街路空間との関係 を考察するため、公園のみに屋外彫刻を設置している都市は除く、 の 3 つである。これらの条件により選出された都市は、福井市、金 沢市、長野市、河内長野市、宇部市の 5 都市である (表 16)。

調査の結果、集まったサンプル数は、福井市 17 基、金沢市 42 基、 長野市 29 基、河内長野市 32 基、宇部市 50 基の計 170 基である。

\section{1 分析の視点と手法}

調査手法は、まず、彫刻本体に関する項目と、設置空間の特徵に 関する項目（図 4)を一覧にした調査シートを各彫刻について作成し、 事前に分かる情報 ${ }^{21) \sim 26)}$ を記入した上で、現地調査により確認した。

次に、彫刻の全貌が可視である領域を可視領域と定義し、この可 視領域の範囲を把握するため、調査シートに $\mathrm{S}=1 / 2,500$ の地図を掲 載し、現地で可視領域の確認を行い記入した。最後に、各彫刻が設 置されている空間の断面図を作成した(図 5)。

現地調査の結果分析については、彫刻・都市空間・見る人の関係 を視覚的な特徵として、(1)彫刻がどのような空間に設置されている のか、(2)任意の視点場から彫刻がどのような角度 (仰角・俯角 : 断面 図より算出注 $\left.{ }^{2}\right)$ )で可視なのか、(3)可視領域・複数可視領域はどのよ うに分布しているのか、(4)彫刻が設置されている空間のプロポーシ ヨン D/H（断面図より算出）の 4 点に着目して考察を行った。

\section{2 彫刻設置空間の分類}

彫刻設置空間を、歩道、公園・広場、施設敷地内、その他の 4 つ に分類し、集計を行った結果、タイプ A の福井市は「歩道」が 14 件 $(82.4 \%)$ と最も多く、タイプ Bの金沢市は「施設敷地内」が 18 件 $(40.9 \%)$ 、長野市は「広場・公園」が 12 件 $(41.4 \%)$ 、タイプ C の河内長野市は「歩道」が 17 件 (51.5\%)、タイプDの宇部市も「歩 道」が 24 件 $(48.0 \%)$ と最も多くなっている（表 17）。

\section{3 仰角 $\cdot$ 俯角}

街路空間における任意の視点場から、彫刻が “どのような角度” で可視であるかを把握し、検討するため、樋口・メルテンスの既往
表 14 彫刻家意向調査の有無（事業プロセスタイプ別）

\begin{tabular}{|c|c|c|c|c|c|c|c|c|}
\hline \multirow{2}{*}{ 回答 } & \multicolumn{2}{|c|}{$\mathrm{A}$} & \multicolumn{2}{|c|}{ B } & \multicolumn{2}{|c|}{$c$} & \multicolumn{2}{|c|}{ D } \\
\hline & 回答数 & 構成比 & 回答数 & 構成比 & 回答数 & \begin{tabular}{|l|} 
構成比 \\
\end{tabular} & \begin{tabular}{|l|} 
回答数 \\
\end{tabular} & 構成比 \\
\hline 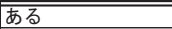 & 5 & $29.4 \%$ & 9 & $81.8 \%$ & 10 & $43.5 \%$ & 10 & $100.0 \%$ \\
\hline ない & 10 & $58.8 \%$ & 2 & $18.2 \%$ & 13 & $56.5 \%$ & 0 & $0.0 \%$ \\
\hline \begin{tabular}{|l} 
不明 - 無回答 \\
\end{tabular} & & $11.8 \%$ & 0 & $0.0 \%$ & 0 & $0.0 \%$ & 0 & $0.0 \%$ \\
\hline 合計 & $\overline{17}$ & $=100.0 \%$ & $\overline{111}$ & $100.0 \%$ & 23 & $100.0 \%$ & 10 & $100.0 \%$ \\
\hline
\end{tabular}

表 15 設置場所決定理由（事業プロセスタイプ別）

\begin{tabular}{|c|c|c|c|c|c|c|c|c|}
\hline \multirow{2}{*}{ 回答 } & \multicolumn{2}{|c|}{ A } & \multicolumn{2}{|c|}{ B } & \multicolumn{2}{|c|}{$\mathrm{c}$} & \multicolumn{2}{|c|}{$\mathrm{D}$} \\
\hline & \begin{tabular}{|l|l|l|l|l|} 
答数 \\
\end{tabular} & 構成比 & 回答数 & 構成比 & 回答数 & 構成比 & 回答数 & 構成比 \\
\hline 作品と周辺環境の適合性（景観） & 2 & $10.0 \%$ & 4 & $25.0 \%$ & 2 & $7.4 \%$ & 4 & 26.79 \\
\hline 彫刻家の意向 & 1 & $5.0 \%$ & 1 & $6.3 \%$ & 0 & $0.0 \%$ & 1 & $6.7 \%$ \\
\hline 市民がよく通り、よく目にする所 & 2 & $10.0 \%$ & 3 & $18.8 \%$ & 7 & $25.9 \%$ & 4 & 26.78 \\
\hline 市民からの要望 & 1 & $5.0 \%$ & 2 & $12.5 \%$ & 0 & $0.0 \%$ & 0 & $0.0 \%$ \\
\hline まちの玄関口、シンボルとなる所 & 4 & $20.0 \%$ & 2 & $12.5 \%$ & 4 & $14.8 \%$ & 0 & $0.0 \%$ \\
\hline $\begin{array}{l}\text { 事業計画などのコンセプトに } \\
\text { 合っているかどうか }\end{array}$ & 3 & $15.0 \%$ & 2 & $12.5 \%$ & 2 & $7.4 \%$ & 0 & $0.0 \%$ \\
\hline 区・市全体の配置バランス & 2 & $10.0 \%$ & 1 & $6.3 \%$ & 0 & $0.0 \%$ & 0 & $0.0 \%$ \\
\hline $\begin{array}{l}\text { 安全性、広さ・金銭的に可能か } \\
\text { どうか }\end{array}$ & 2 & $10.0 \%$ & 1 & 6. 3\% & 1 & $3.7 \%$ & 5 & 33. 3in \\
\hline 公用地であること & 0 & $0.0 \%$ & 0 & $0.0 \%$ & 2 & $7.4 \%$ & 0 & 0.0 .4 \\
\hline その他 & 1 & $5.0 \%$ & 0 & $0.0 \%$ & 0 & $18.5 \%$ & 1 & 6.70 \\
\hline 不明 ·無回答 & 2 & $10.0 \%$ & 0 & $0.0 \%$ & 4 & $14.8 \%$ & 0 & $0.0 \%$ \\
\hline 合計 & 20 & $100.0 \%$ & 16 & $100.0 \%$ & 27 & $100.0 \%$ & 15 & $100.0 \%$ \\
\hline
\end{tabular}

表 16 各タイプ代表 現地調査都市

\begin{tabular}{|c|c|c|c|}
\hline \multicolumn{2}{|r|}{ 事業プロセスタイプ } & 䧇名 & 各都市の事業の特徵 \\
\hline A & 都市デザイン型 & 福井市 & $\begin{array}{l}\text { オーダーメイドヌは、コンペを開催して彫刻を入手して } \\
\text { おり、基本計画に基づき彫刻を設置 } \\
\end{array}$ \\
\hline B & \multirow[t]{2}{*}{ 住民合意形成型 } & 金沢市 & 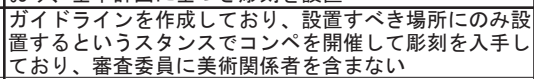 \\
\hline & & 長野市 & $\begin{array}{l}\text { 長期間事業を継続的に実施しており、市内の全彫刻が } \\
\text { オーダーメイ゙で制作されている }\end{array}$ \\
\hline C & 行政主導型 & $\begin{array}{l}\text { 河内 } \\
\text { 長野市 } \\
\end{array}$ & $\begin{array}{l}\text { ふるさと創生1億円事業により事業を開始したが、金鋅 } \\
\text { 的な課題もあり事業は現在計画途中で休止している }\end{array}$ \\
\hline & 制作者意向重視型 & 宇部市 & \begin{tabular}{|l} 
長期間事業を夤施しており、彫刻界では登童門的存在て \\
ある現代日本彫刻展の開催により彫刻を入手している
\end{tabular} \\
\hline \multicolumn{4}{|c|}{ 彫刻本体に関する項目》 } \\
\hline \multicolumn{2}{|r|}{$\begin{array}{l}\cdot \text { - 作者名 } \cdot \text { 素柏 } \\
\cdot \text { 設置年度 }\end{array}$} & $\begin{array}{l}\text { ・ サイ } \\
\text { ·表晲 } \\
\text { ・作品 }\end{array}$ & 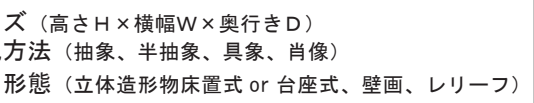 \\
\hline \multicolumn{4}{|c|}{ 《設置空間に関する項目》 } \\
\hline \multicolumn{4}{|c|}{ 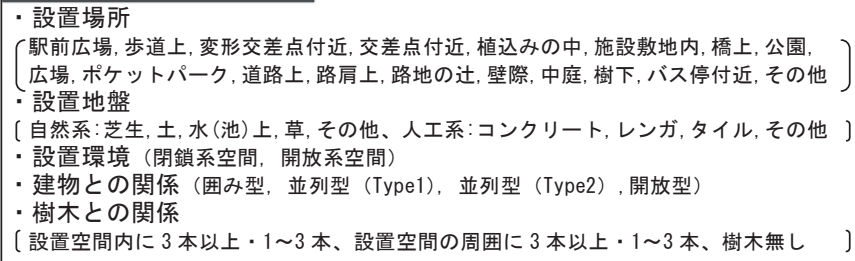 } \\
\hline
\end{tabular}

図 4 現地調査項目

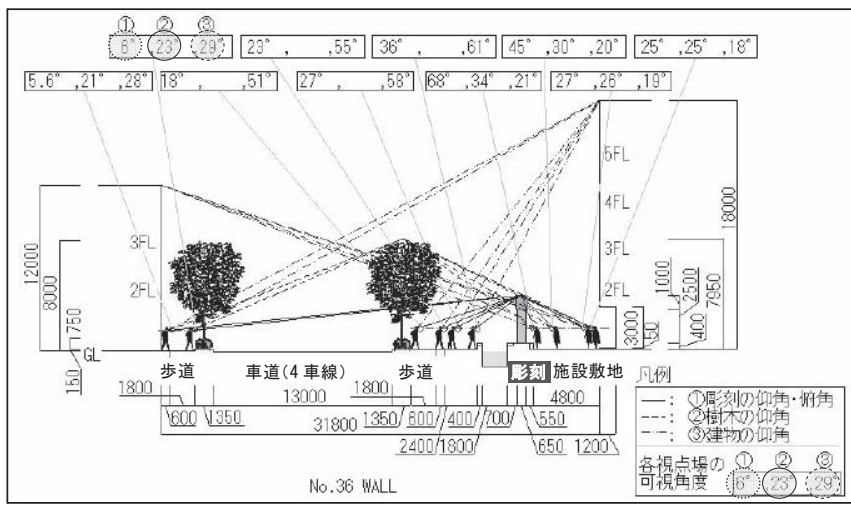

図 5 現地調査作成断面図例（金沢市：No. 36WALL）

表 17 彫刻設置空間の分類

\begin{tabular}{|c|c|c|c|c|c|c|}
\hline \multirow{2}{*}{ 設置空間分類項目 } & 福井 & 金沢 & 長野 & 河内長野 & \multicolumn{2}{|c|}{ 宇部 } \\
\hline & 該当数 構成比 & 該当数 構成比 & 該当数 構成比 & 該当数 構成比 & 該当数 & 構成比 \\
\hline 步道 & $14824 \%$ & \begin{tabular}{|l|r|}
12 & $27.3 \%$ \\
\end{tabular} & \begin{tabular}{|l|l|}
7 & $24.1 \%$ \\
\end{tabular} & 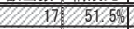 & 24 & $48 \%$ \\
\hline 広場·公園 & \begin{tabular}{|l|l|}
1 & $5.9 \%$ \\
\end{tabular} & \begin{tabular}{|l|l|}
12 & $27.3 \%$ \\
\end{tabular} & \begin{tabular}{|l|l|}
12 & $41.4 \%$ \\
\end{tabular} & \begin{tabular}{|l|l|}
12 & $36.4 \%$ \\
\end{tabular} & 15 & $30.0 \%$ \\
\hline 施設敷地内 & \begin{tabular}{|l|l|}
2 & $11.8 \%$ \\
\end{tabular} & \begin{tabular}{|l|l|}
18 & $40.9 \%$ \\
\end{tabular} & \begin{tabular}{|l|l|l|}
10 & $34.5 \%$ \\
\end{tabular} & $9.1 \%$ & 11 & $22.0 \%$ \\
\hline その他 & \begin{tabular}{l|l}
$0.0 \%$ \\
\end{tabular} & \begin{tabular}{|l|l|}
2 & $4.5 \%$ \\
\end{tabular} & $0.0 \%$ & $3.0 \%$ & 0 & $0.0 \%$ \\
\hline 合計 & $\begin{array}{l}17 \\
17\end{array}$ & $\begin{array}{l}44 \\
\end{array}$ & \begin{tabular}{|l|l|l|l|l|}
29 & $100.0 \%$ \\
\end{tabular} & \begin{tabular}{|l|l|l|}
33 & $100.0 \%$ \\
\end{tabular} & 50 & $100.0 \%$ \\
\hline
\end{tabular}

研究 ${ }^{27)}$ により提唱されている角度注3)である “仰角 $9^{\circ} \cdot 18^{\circ} \cdot 27^{\circ}$ ・ $45^{\circ}$ 、俯角 $10^{\circ} ”$ の 5 つ角度で可視である視点場を取り上げ、分 析を行った。 
集計の結果、全都市で「該当なし」が最も多く、福井市 20 件 $(39.2 \%) 、$ 金沢市 53 件 $(34.0 \%)$ 、長野市 35 件 (25.7\%)、河内長野 市 49 件 (41. $2 \%$ )、宇部市 44 件 (25.1\%) となっている (表 18$) 。$

次に多いのは都市により異なり、福井市は仰角 $27^{\circ}$ が 10 件 (19.6\%)、金沢市は仰角 $18^{\circ}$ が 33 件 $(21.2 \%)$ 、長野市は仰角 $27^{\circ}$ が 33 件 $(24.3 \%)$ 、河内長野市は仰角 $45^{\circ}$ が 23 件 (19.3\%)、宇部 市は仰角 $9^{\circ}$ が 38 件 (21.7\%) という結果になっている(表 18)。

最後に、「俯角 $10^{\circ} 」 て ゙$ 彫刻を見ることの出来る視点場は、福井 市 2 件 $(3.9 \%)$ 、金沢市 3 件 $(1.9 \%)$ 、長野市 3 件 $(2.2 \%)$ 、河内長野 市 2 件 (1. $7 \%$ )、宇部市 9 件 (5.1\%)であり、全都市で非常に少ない という結果であった(表 18)。

従って、全都市で既往研究による望ましい角度に該当しない場合 が最も多いものの、福井市、金沢市、長野市では、彫刻や建築を視 対象とした場合に望ましい仰角注 ${ }^{3)}$ とされる仰角 $27^{\circ} \cdot 18^{\circ}$ が採用 されやすいことが明らかになった。

また、俯角 $10^{\circ}$ が意味する “自然な視線の角度 27)” 注3) で彫刻の 全貌を捉える事の出来る視点場は全都市で非常に少ないことが明ら かになった。

\section{4 可視領域 $\cdot$ 複数可視領域}

彫刻の全貌が可視である視点場注 4 ) を可視領域、複数の彫刻の全貌 が可視である視点場を複数可視領域と定義し、可視状況を調查した。

可視領域については、槙の “奥性 28)” や、鳴海の “空間の連続性 を演出する 29 ) ”という考え方を踏まえると、可視領域を連続させる ことで回遊性を生み出すことが考えられる。さらには、複数可視領 域が、その場所における滞留性を生み出すことが考えられる。従っ て、ここでは可視領域の連続性と複数可視領域の存在する場所に着 目し、可視状況の考察を行った。

福井市では、可視領域は公園や施設敷地内（図 6 : 彫刻 No.4）な ど、滞留性のある場所では面的に広がり、通り沿いやお堀周辺など の動線となる場所では連続して線的に分布している。また、複数可 視領域は最大 2 つが可視である場所が歩道上に 8 箇所点在している (図 6)。

金沢市では、JR 金沢駅から兼六園や金沢 21 世紀美術館までの動 線となっている通りを、彫刻設置基本方針 $\left.{ }^{17}\right)$ でアートアベニューと して位置づけ、この通り沿いに集中的に彫刻を設置している。従っ て、可視領域は実際には連続していないが、動線として連続してい る。また、複数可視領域は、駅前や変形交差点付近、主要施設前の 広場など、特徽的な場所にある。つまり、目印となる場所や、滞留 性の生まれやすい場所に複数可視領域があるという事が明らかにな った(図 7)。

長野市では、可視領域が歩道上に点在している。主要公共施設で ある市役所や図書館の敷地内 (図 8: 彫刻 No.12) には可視領域が面的 に広がっており、城山公園内には広範囲にかつ集中的に可視領域が 分布している。また、複数可視領域は最大 3 つが可視である場所が 存在し、その大部分は彫刻が集中設置されている城山公園エリアに 存在する。複数可視である箇所は非常に少ないが、面積的には非常 に広い複数可視領域が城山公園エリアに存在する（図 8)。

河内長野市では、可視領域は対象エリア全域に点在しており、駅 周辺エリアでは、河内長野駅前と長野中学校の前に集中している。 複数可視領域は、この可視領域が集中している箇所のみに分布し、
表 18 仰角 ・俯角の検討

\begin{tabular}{|c|c|c|c|c|c|c|c|}
\hline & \multicolumn{6}{|c|}{ 角度 } & \multirow{2}{*}{$\begin{array}{c}\text { 合計 } \\
\text { 構成比 }(\%)\end{array}$} \\
\hline & 仰角 $9^{\circ}$ & 仰角 $18^{\circ}$ & 仰角 $27^{\circ}$ & 仰角 $45^{\circ}$ & 俯角 $10^{\circ}$ & 該当なし & \\
\hline \multirow{2}{*}{ A. 福井市 } & 8 & 9 & 10 & 2 & 4 & 20 & 51 \\
\hline & $15.7 \%$ & $17.6 \%$ & $19.6 \%$ & $3.9 \%$ & 3.90 & $392 \%$ & $100.0 \%$ \\
\hline \multirow{2}{*}{ B. 金沢市 } & "177 & 33 & 26 & 24 & 3 & 53 & $\bar{~} 1156$ \\
\hline & $10.9 \%$ & $21.2 \%$ & $16.7 \%$ & $15.4 \%$ & $10 \%$ & $34: 0 \%$ & $100.0 \%$ \\
\hline \multirow{2}{*}{ B. 長野市 } & 21 & 27 & 33 & 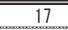 & 3 & 35 & $\overline{c 136}$ \\
\hline & $15.4 \%$ & $19.9 \%$ & $24.3 \%$ & $12.5 \%$ & 2.23 & $2579 \%:$ & $100.0 \%$ \\
\hline \multirow{2}{*}{ C. 河内長野市 } & 3 & 20 & 22 & 23 & 2 & 49 & 119 \\
\hline & $2.5 \%$ & $16.8 \%$ & $18.5 \%$ & $19.3 \%$ & 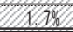 & $412 \%$ & $100.0 \%$ \\
\hline \multirow{2}{*}{ D. 宇部市 } & 38 & 34 & 31 & 19 & 4 & 44 & 175 \\
\hline & 21.70 & $19.4 \%$ & $17.7 \%$ & $10.9 \%$ & 5,0 & $25: 19:$ & $100.0 \frac{0}{m}$ \\
\hline
\end{tabular}
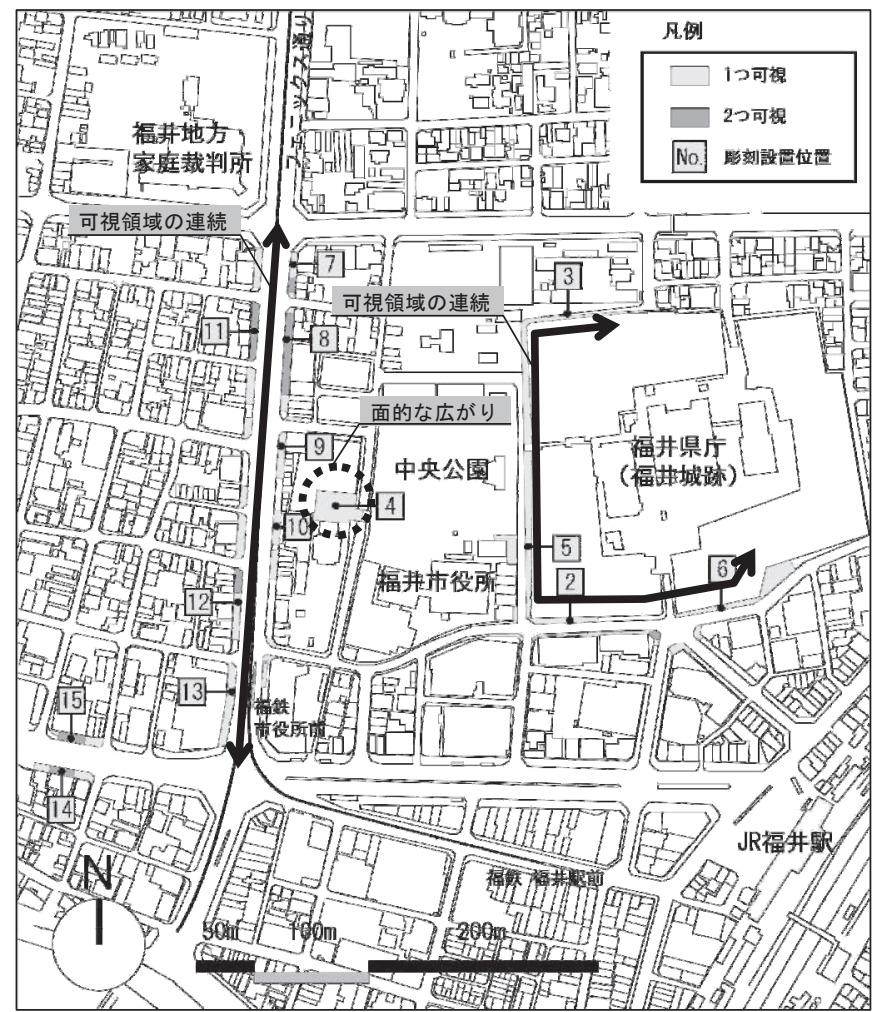
図 6 福井市 複数可視領域図

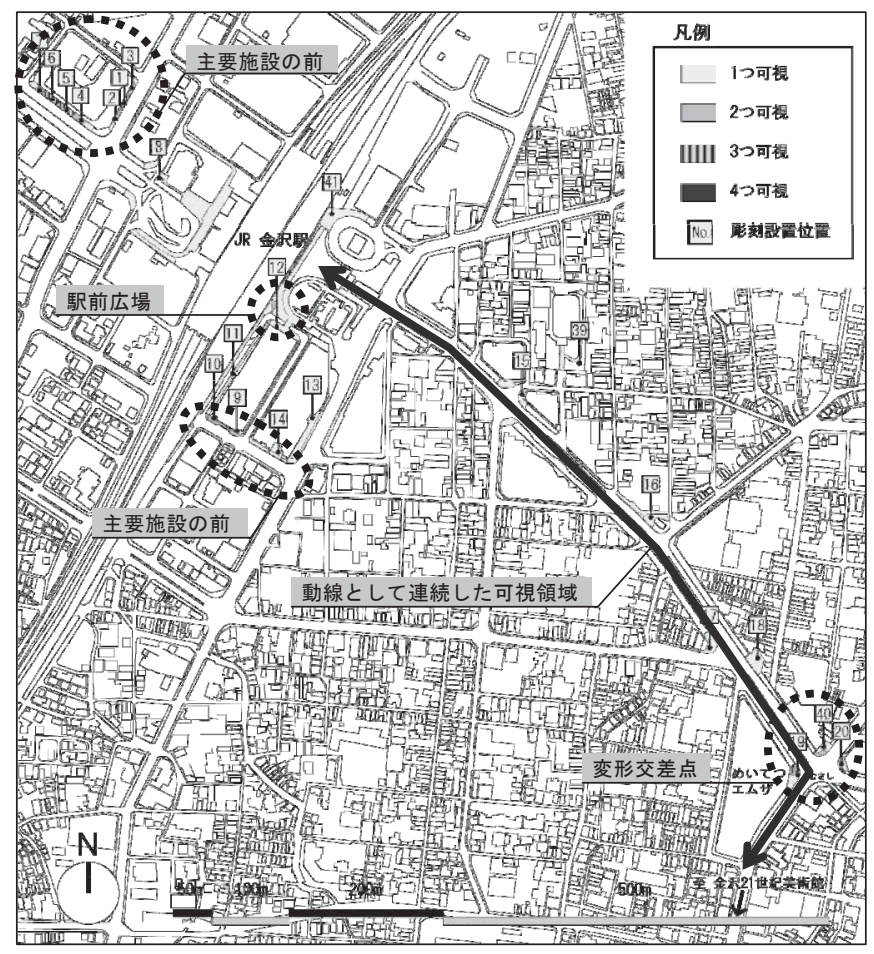

図 7 金沢市 複数可視領域図（駅周辺エリア） 
最多の 4 つの彫刻が可視であるのは長野中学校前の変形交差点付近 の歩道上である。また、河内長野駅前の空中街路上から、2つの彫 刻が可視であるという点が他都市と大きく異なる(図 9)。

宇部市では、宇部新川駅から郵便局までの通り沿いと、真締川の 河川公園において可視領域が長く連続している。その結果、彫刻設 置エリア全体で可視領域が連続している。また、複数可視領域は宇 部新川駅から市役所までの通り沿いで最大 8 つが可視の場所があり、 図書館の敷地内には面的に広がっている。その結果、可視領域同様 に、彫刻設置エリア全体に複数可視領域が分布している(図 10)。

以上 5 都市の分析結果を一覧(表 19)にして考察を行うと、まず可 視領域については、タイプ A 都市デザイン型の福井市、タイプ D 制 作者意向重視型の宇部市の場合に連続しており、タイプ B 金沢市の 場合は動線とし連続しているということが明らかになった。また、 複数可視領域の特徴は各都市で異なるため、共通的な特徵は見られ なかつた。

従って、可視領域の連続により回遊性を、複数可視領域の計画に より滞留性を創出する事で、屋外彫刻の設置により都市空間に一体 感と独自性を生み出すことが可能なのではないかと考えられる。

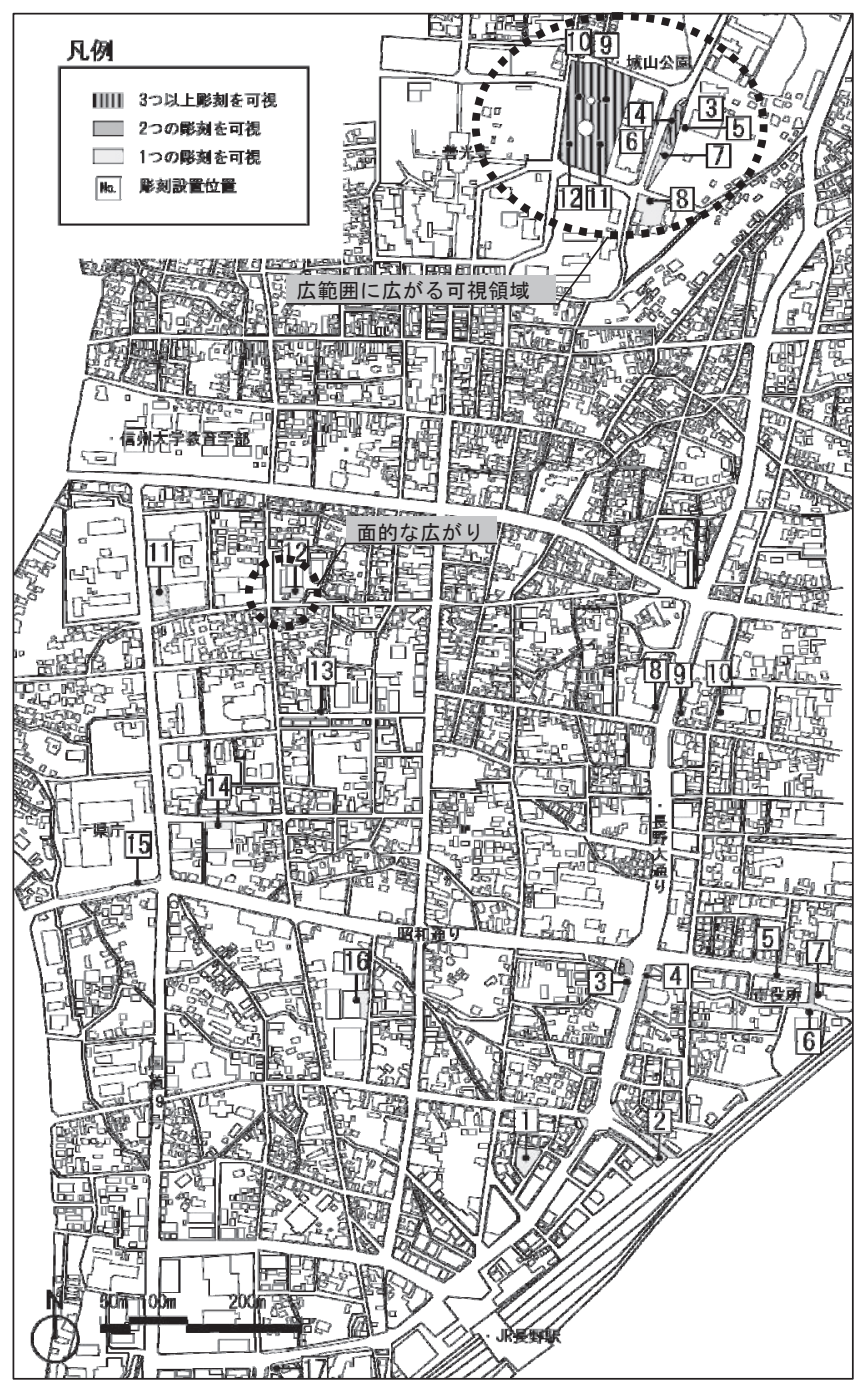

図 8 長野市 複数可視領域図
5. 5 設置空間のプロポーション

設置空間のプロポーションを表す指標として D/H を用いることと

し、本研究では下記の 3 つの D/H を設定した(図 11)。

ロ 3 つの $\mathrm{D} / \mathrm{H}$

D/H1): 設置空間全幅（D1）／最大建物又は最大樹木高さ（H1） D/H(2): 設置空間左端から彫刻中心間距離（D2）/彫刻高さ（H2） D/H(3): 設置空間右端から彫刻中心間距離（D3）/彫刻高さ（H2）

この 3 つの $\mathrm{D} / \mathrm{H}$ を計測し、その集計結果について既往の知見注 5$)$ を踏まえた考察を行うと、まず $\mathrm{D} / \mathrm{H}(1)$ は福井市では「 $1 \leqq \mathrm{D} / \mathrm{H}<2$ 」 が 11 件 (64.7\%)、金沢市では「D/H<1」が 15 件 (35.7\%)、河内長 野市では「 $1 \leqq \mathrm{D} / \mathrm{H}<2 」$ が 10 件 $(31.3 \%)$ と $\mathrm{D} / \mathrm{H}<2$ である場合が最

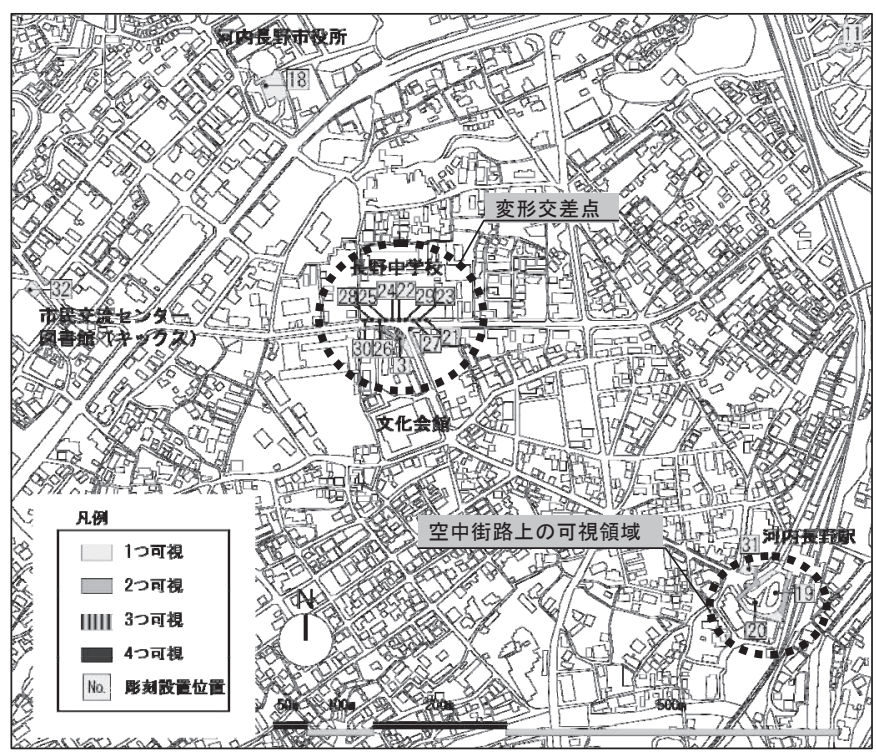

図 9 河内長野市 複数可視領域図（駅周辺エリア）

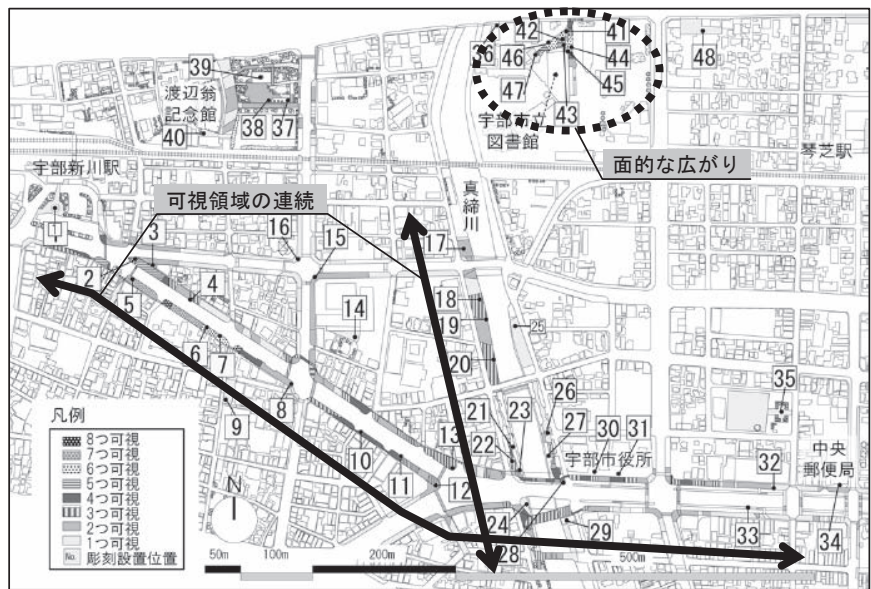

図 10 宇部市 複数可視領域図

表 19 可視領域・複数可視領域の検討

\begin{tabular}{|c|c|c|c|}
\hline 事業プロセスタイプ & 代表都市 & 可視領域の連続性 & 複数可視領域の場所 \\
\hline $\begin{array}{c}\text { タイプA } \\
\text { 都市デザイン型 }\end{array}$ & 福井市 & |実際に連続している & 歩道上に点々とある \\
\hline \multirow{2}{*}{$\begin{array}{c}\text { タイプB } \\
\text { 住民合意形成型 }\end{array}$} & 金沢市 & 動線として連続している & $\begin{array}{l}\text { 変形交差点付近などの特徴を } \\
\text { 持った場所と、滞留性のある } \\
\text { 駅前や広場にある }\end{array}$ \\
\hline & 長野市 & 公園内や市役所前でのみ連続 & 公園内や市役所前にある \\
\hline $\begin{array}{l}\text { タイプC } \\
\text { 行政主導型 }\end{array}$ & 河内長野市 & 3箇所でのみ連続が見られる & $\begin{array}{l}\text { 駅前、中学校前、公園北側の } \\
\text { 交差点にある }\end{array}$ \\
\hline $\begin{array}{c}\text { タイプD } \\
\text { 制作者意向重視型 }\end{array}$ & 宇部市 & 実際に連続している & $\begin{array}{l}\text { エリア全体に連続的に } \\
\text { 広がっている }\end{array}$ \\
\hline
\end{tabular}


も多くなっており、“広々とした感じ: 芦原 ${ }^{30}$ ” であるが “囲いの 始まり : スプライゲン ${ }^{30)}$ ”である空間に彫刻が設置されているとい う事が明らかになった(表 20)。

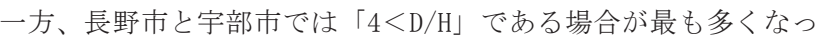

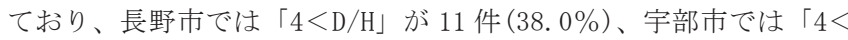
D/H」が 37 件 (74.0\%) という結果であることから、“囲われた感じは 消失 : スプライゲン ${ }^{25)}$ ”した空間に彫刻が設置されているという事 が明らかになった (表 20)。

次に、D/H(2)は全都市で「 $4<\mathrm{D} / \mathrm{H} 」$ の場合が最も多く、福井市 9 件 (52. 9\%)、金沢市 27 件 (64.3\%)、長野市 23 件 (80.0\%)、河内長 野市 25 件 (78.1\%)、宇部市 45 件 (90.0\%) となっている(表 20)。

最後に、D/H(3)は河内長野市では「D/H<1」が 11 件 (34.4\%) と最 も多くなっているが、他の 4 都市では「 $4<\mathrm{D} / \mathrm{H} 」$ が最も多く、福井 市 11 件 (64.7\%)、金沢市 21 件 (50.0\%)、長野市 23 件 (79.0\%)、宇 部市 39 件 (78.0\%) となっている (表 20)。

従って、D/H(1)のみに都市による違いが見られ、彫刻が設置されて いる都市自体の空間プロポーションは異なるが、事業プロセスタイ プの違いによる設置空間の大きな違いは見られなかった。

\section{6 事業プロセスタイプごとの景観の基本的構成}

以上の分析結果を、本研究で分類した事業プロセスタイプ(事業の 特徵)との関係について都市別に再度整理した (表 21)。

まず、タイプ A 都市デザイン型の福井市の場合、景観形成を目的 とし、事業計画に合った設置場所を彫刻の制作前に設定し、その場 所の景観や場所性を考慮して彫刻が制作されている。このようなプ ロセスを経てつくられた彫刻設置空間は歩道上に多く、望ましいと 考えられる仰角で可視である視点場も多く存在する。また、可視領 域の連続による回遊性が生み出されている。

タイプ B 住民合意形成型の金沢市の場合、まちづくり、景観形成 を目的とし、住民や彫刻家一の意向調查を行いながら、市民が良く 通り、よく目にする所にその場所の景観・場所性を考慮した彫刻が 制作、設置されている。このようなプロセスを経てつくられた彫刻 設置空間は、望ましいと考えられる仰角で可視である視点場が多く 存在し、可視領域の連続性により回遊性が生み出されている。また、 複数可視領域が目印となる場所や滞留性のある場所に存在し、施設 敷地内に多く設置されていることから、屋外彫刻の設置により独自 性や一体感が生み出されているという特徵がある。

タイプ B 住民合意形成型の長野市の場合、文化環境の創造を目的 とし、21 年以上継続的に事業が行われているため 101 基以上の非常 に多くの彫刻が屋外に設置されている。設置場所の決定にあたって は、周辺環境との適合性や市民からの要望により設置場所が決めら れ、住民と彫刻家への意向調査も実施されている。このようなプロ セスを経てつくられた彫刻設置空間は、望ましいと考えられる仰角 で可視である視点場が多く存在し、広場や公園といった空間に点在 しているという特徵がある。

タイプ C 行政主導型の河内長野市の場合、住民や彫刻家の意向調 查を行わず、設置場所を考慮した彫刻の制作は行わずに市民が良く 通りよく目にするところに彫刻が設置されている。このようなプロ セスを経てつくられた彫刻設置空間は、歩道に設置されている場合 が多く、設置空間自体のプロポーションは、“広々とした感じ、囲い の始まり注5)”といった空間となっている。また、可視領域や複数可

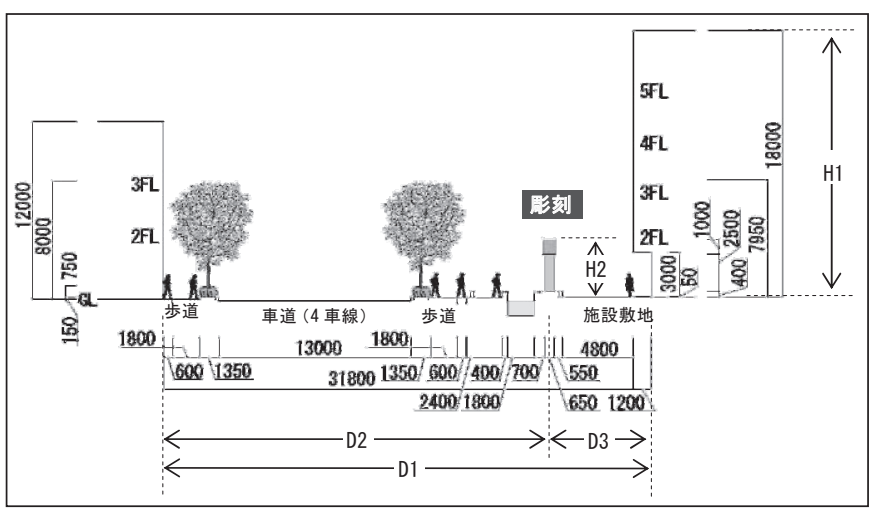

図 11 設置空間のプロポーション D/H

表 20 設置空間のプロポーション $\mathrm{D} / \mathrm{H}$

\begin{tabular}{|c|c|c|c|c|c|c|}
\hline \multirow{2}{*}{ A. 福井市 } & \multicolumn{2}{|c|}{ D/H(1) } & \multicolumn{2}{|c|}{$\mathrm{D} / \mathrm{H}(2)$} & \multicolumn{2}{|c|}{$\mathrm{D} / \mathrm{H}(3)$} \\
\hline & 合計 & 構成比 (\%) & 合計 & 構成比 $(\%)$ & 合計 & 構成比 (\%) \\
\hline$D / H<1$ & 2 & $11.8 \%$ & 0 & $0.0 \%$ & 0 & $0.0 \%$ \\
\hline $1 \leqq D / H<2$ & 11 & $64.7 \%$ & 3 & $17.6 \%$ & 1 & $5.9 \%$ \\
\hline $2 \leqq D / H<3$ & 2 & $11.8 \%$ & 5 & $29.4 \%$ & 3 & $17.6 \%$ \\
\hline $3 \leqq D / H \leqq 4$ & 0 & $0.0 \%$ & 0 & $0.0 \%$ & 2 & $11.8 \%$ \\
\hline $4<\mathrm{D} / \mathrm{H}$ & 2 & $11.8 \%$ & 9 & $52.9 \%$ & 11 & $64.7 \%$ \\
\hline 合計 & 17 & $100.0 \%$ & 17 & $100.0 \%$ & 17 & $100.0 \%$ \\
\hline \multirow{2}{*}{ B. 金沢市 } & \multicolumn{2}{|c|}{$\mathrm{D} / \mathrm{H}(1)$} & \multicolumn{2}{|c|}{$\mathrm{D} / \mathrm{H}(2)$} & \multicolumn{2}{|c|}{$\mathrm{D} / \mathrm{H}(3)$} \\
\hline & 合計 & 構成比 (\%) & 合計 & 構成比 $(\%)$ & 合計 & 構成比 $(\%)$ \\
\hline$D / H<1$ & 15 & $35.7 \%$ & 1 & $2.4 \%$ & 7 & $16.7 \%$ \\
\hline $1 \leqq D / H<2$ & 14 & $33.3 \%$ & 4 & $9.5 \%$ & 4 & $9.5 \%$ \\
\hline $2 \leqq D / H<3$ & 5 & $11.9 \%$ & 3 & $7.1 \%$ & 5 & $11.9 \%$ \\
\hline $3 \leqq D / H \leqq 4$ & 3 & $7.1 \%$ & 7 & $16.7 \%$ & 5 & $11.9 \%$ \\
\hline $4<D / H$ & 5 & $11.9 \%$ & 27 & $64.3 \%$ & 21 & $50.0 \%$ \\
\hline 合計 & 42 & $100.0 \%$ & 42 & $100.0 \%$ & 42 & $100.0 \%$ \\
\hline \multirow{2}{*}{ B. 長野市 } & \multicolumn{2}{|c|}{$\mathrm{D} / \mathrm{H}$ (1) } & \multicolumn{2}{|c|}{$\mathrm{D} / \mathrm{H}(2)$} & \multicolumn{2}{|c|}{$\mathrm{D} / \mathrm{H}$ (3) } \\
\hline & 合計 & 構成比 (\%) & 合計 & 構成比 $(\%)$ & 合計 & 構成比 (\%) \\
\hline$D / H<1$ & 2 & 7. $0 \%$ & 0 & $0.0 \%$ & 0 & $0.0 \%$ \\
\hline $1 \leqq D / H<2$ & 7 & $24.0 \%$ & 5 & $17.0 \%$ & 2 & $7.0 \%$ \\
\hline $2 \leqq D / H<3$ & 4 & $14.0 \%$ & 0 & $0.0 \%$ & 2 & 7. $0 \%$ \\
\hline $3 \leqq D / H \leqq 4$ & 5 & $17.0 \%$ & 1 & $3.0 \%$ & 2 & 7.0\% \\
\hline $4<D / H$ & 11 & $38.0 \%$ & 23 & $80.0 \%$ & 23 & $79.0 \%$ \\
\hline 合計 & 29 & $100.0 \%$ & 29 & $100.0 \%$ & 29 & $100.0 \%$ \\
\hline \multirow{2}{*}{ C. 河内長野市 } & \multicolumn{2}{|c|}{$\mathrm{D} / \mathrm{H}(1)$} & \multicolumn{2}{|c|}{$\mathrm{D} / \mathrm{H}(2)$} & \multicolumn{2}{|c|}{ D/H(3) } \\
\hline & 合計 & 構成比 (\%) & 合計 & 構成比 $(\%)$ & 合計 & 構成比 (\%) \\
\hline $\mathrm{D} / \mathrm{H}<1$ & 2 & $6.3 \%$ & 2 & $6.3 \%$ & 11 & $34.4 \%$ \\
\hline $1 \leqq D / H<2$ & 10 & $31.3 \%$ & 0 & $0.0 \%$ & 4 & $12.5 \%$ \\
\hline $2 \leqq D / H<3$ & 9 & $28.1 \%$ & 3 & $9.4 \%$ & 4 & $12.5 \%$ \\
\hline $3 \leqq D / H \leqq 4$ & 5 & $15.6 \%$ & 2 & $6.3 \%$ & 4 & $12.5 \%$ \\
\hline $4<D / H$ & 6 & $18.8 \%$ & 25 & $78.1 \%$ & 9 & $28.1 \%$ \\
\hline 合計 & 32 & $100.0 \%$ & 32 & $100.0 \%$ & 32 & $100.0 \%$ \\
\hline \multirow{2}{*}{ D. 宇部市 } & \multicolumn{2}{|c|}{$\mathrm{D} / \mathrm{H}(1)$} & \multicolumn{2}{|c|}{$\mathrm{D} / \mathrm{H}(2)$} & \multicolumn{2}{|c|}{$\mathrm{D} / \mathrm{H}(3)$} \\
\hline & 合計 & 構成比 (\%) & 合計 & 構成比 $(\%)$ & 合計 & 構成比 (\%) \\
\hline $\mathrm{D} / \mathrm{H}<1$ & 1 & $2.0 \%$ & 1 & $2.0 \%$ & 1 & $2.0 \%$ \\
\hline $1 \leqq D / H<2$ & 1 & $2.0 \%$ & 1 & $2.0 \%$ & 4 & $8.0 \%$ \\
\hline $2 \leqq D / H<3$ & 4 & $8.0 \%$ & 3 & $6.0 \%$ & 3 & $6.0 \%$ \\
\hline $3 \leqq D / H \leqq 4$ & 7 & $14.0 \%$ & 0 & $0.0 \%$ & 3 & $6.0 \%$ \\
\hline $4<D / H$ & 37 & $74.0 \%$ & 45 & $90.0 \%$ & 39 & $78.0 \%$ \\
\hline 合計 & 50 & $100.0 \%$ & 50 & $100.0 \%$ & 50 & $100.0 \%$ \\
\hline
\end{tabular}

視領域は点在するという特徴がある。

タイプ D 制作者意向重視型の宇部市の場合、彫刻設置によりまち づくり、景観形成、文化環境の創造といった様々な目的を果たそう としている。事業は継続的に行われ、101 基以上の非常に多くの彫 刻が設置場所を考慮せずに設置されている。また、彫刻家に対する 意向調查のみを行い“安全性、広さ・金銭的に可能から゙うか”を理 由に彫刻が設置されている。このようなロセスを経てつくられた彫 刻設置空間は、可視領域と複数可視領域が連続しており、回遊性が 生み出されているという特徴がある。 
表 21 事業プロセスタイプと景観の基本的構成の関係

\begin{tabular}{|c|c|c|c|c|c|c|c|}
\hline \multicolumn{3}{|c|}{ 都市名 } & 福井市 & 金沢市 & 長野市 & 河内長野市 & 宇部市 \\
\hline \multicolumn{3}{|c|}{ 事業プロセスタイプ } & $\begin{array}{c}\text { タイプA } \\
\text { 都市デザイン型 }\end{array}$ & $\begin{array}{c}\text { タイプB } \\
\text { 住民合意形成型 }\end{array}$ & $\begin{array}{c}\text { タイプB } \\
\text { 住民合意形成型 }\end{array}$ & $\begin{array}{l}\text { タイプC } \\
\text { 行政主導型 }\end{array}$ & $\begin{array}{l}\text { タイプD } \\
\text { 制作者意向重視型 }\end{array}$ \\
\hline \multicolumn{3}{|c|}{ 目的 } & 景観形成 & $\begin{array}{l}\text { まちづくり } \\
\text { 景観形成 }\end{array}$ & 文化環境の創造 & $\begin{array}{c}\text { その他 } \\
\text { (ふるさとづくり) }\end{array}$ & $\begin{array}{c}\text { まちづくり } \\
\text { 景観形成 } \\
\text { 文化環境の創造 }\end{array}$ \\
\hline \multirow{6}{*}{$\begin{array}{l}\text { 事 } \\
\text { 業 } \\
\text { 特 } \\
\text { 徵 }\end{array}$} & \multicolumn{2}{|c|}{ 事業継続年数 } & $6 \sim 10$ 年 & $6 \sim 10$ 年 & 21 年以上 & $6 \sim 10$ 年 & 21 年以上 \\
\hline & \multicolumn{2}{|c|}{ 事業の継続性 } & $\begin{array}{c}\text { 継続的に行われる予定だったが、 } \\
\text { 何らかの理由により休 }\end{array}$ & 継続的ではない & 継続的 & $\begin{array}{c}\text { 継続的に行われる予定だつたが、 } \\
\text { 何らかの理由により休止 }\end{array}$ & 継続的 \\
\hline & \multicolumn{2}{|c|}{ 設置場所の考慮 } & $\begin{array}{l}\text { 予め設置場所を設定し } \\
\text { その場所の景観・場所性を } \\
\text { 考慮した彫刻を制作、設置 }\end{array}$ & $\begin{array}{l}\text { 予め設置場所を設定し、 } \\
\text { その場所の景観・場所性を } \\
\text { 考慮した彫刻を制作、設置 }\end{array}$ & $\begin{array}{l}\text { 予め設置場所を設定し } \\
\text { その場所の景観・場所性を } \\
\text { 考慮した彫刻を制作、設置 }\end{array}$ & $\begin{array}{l}\text { 設置場所を設定せずに } \\
\text { 彫刻を制作・設置 }\end{array}$ & $\begin{array}{l}\text { 設置場所を設定せずに } \\
\text { 彫刻を制作設置 }\end{array}$ \\
\hline & \multicolumn{2}{|c|}{ 設置場所の決定理由 } & $\begin{array}{l}\text { 事業計画などのコンセプトに } \\
\text { 合っているがうか }\end{array}$ & $\begin{array}{l}\text { 市民が良く通り、 } \\
\text { よく目にするところ }\end{array}$ & $\begin{array}{c}\text { 彫刻と周辺環境の適合性（景観） } \\
\text { 市民からの要望 }\end{array}$ & $\begin{array}{l}\text { 市民が良く通り、 } \\
\text { よく目にするところ }\end{array}$ & $\begin{array}{c}\text { 安全性、広さ・金銭的に } \\
\text { 可能かどうかか }\end{array}$ \\
\hline & \multicolumn{2}{|c|}{ 設置数 } & 21 40基 & 21 40基 & 101基以上 & 21 40基 & 101基以上 \\
\hline & 音向調查 & 住民 & なし & あり & あり & なし & なし \\
\hline \multirow{5}{*}{$\begin{array}{c}\text { 景 } \\
\text { 観 } \\
\text { 基 } \\
\text { 本 } \\
\text { 的 } \\
\text { 構 } \\
\text { 成 }\end{array}$} & \multirow{3}{*}{ 視覚的特性 } & 仰角 & 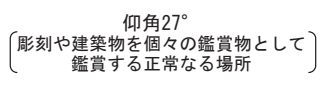 & $\begin{array}{c}\text { 仰角 } 18^{\circ} \\
(\text { 一群の建築としてみる場合に } \\
\text { 良い仰角 }\end{array}$ & 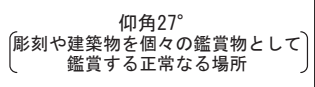 & 仰角 $45^{\circ}$ & 仰角 $9^{\circ}$ \\
\hline & & $\begin{array}{c}\begin{array}{c}\text { 可視領域の } \\
\text { 連続性 }\end{array} \\
\end{array}$ & 連続 $\Rightarrow$ 回遊性の創出 & 連続 $\Rightarrow$ 回遊性の創出 & 点在 & 点在 & 連続 $\Rightarrow$ 回遊性の創出 \\
\hline & & 複数可視領域 & 点在 (歩道) & $\begin{array}{l}\text { 目印となる場所 } \\
\text { 滞留性のある場所 }\end{array}$ & $\begin{array}{c}\text { 点在 } \\
(\text { 公園·市役所前) }\end{array}$ & (駅前· 中㤐校前 $\cdot$ 交差点) & 連続 \\
\hline & \multirow{2}{*}{\begin{tabular}{|l|} 
設置空間の \\
特徵
\end{tabular}} & $\mathrm{D} / \mathrm{H}(1)$ & （広々とした感じ、囲いの始まり） & (広々とした感し，囲いの始まり) & ( 囲いの消失) & (広々とした感じ、囲いの始まり) & (囲いの消失) \\
\hline & & 設置空間 & 歩道 & 施設敷地内 & 広場·公園 & 歩道 & 歩道 \\
\hline
\end{tabular}

ここまでの都市別の事業の特徴と設置空間の景観特性との関係性 についての考察より、事業の目的違いによる傾向とプロセスの違い による傾向があると考えられる。

まず、目的の違いによる傾向としては、まちづくりを目的とした 事業 (金沢市、宇部市)の場合、可視領域が連続し、複数可視領域は 滞留性や連続性をもつ空間となっており、彫刻設置空間全体が一体 感や独自性をもつ空間となっている。景観形成を目的とした事業 (福 井市、金沢市、宇部市)の場合、事業プロセスは異なるが、可視領域 の連続による都市空間の回遊性が生み出されている。文化環境の創 造を目的とした事業 (長野市、宇部市)の場合、事業が継続的に行わ れ、彫刻家への意向調查を行うというプロセスで実施されるが、彫 刻設置空間の景観の基本的構成に関しては共通の特徵は見られなか った。

また、事業プロセスの違いによる傾向としては、住民と彫刻家一 の意向調查を行っている場合、設置場所が歩道以外の滞留性のある 場所に設置されるという傾向あるという事が明らかになった。一方、 設置場所を予め設定し、その場所の景観や場所性を考慮した彫刻を 制作、設置した場合、望ましいと考えられる仰角で彫刻が可視であ る視点場が多く存在するという事が明らかになった。

\section{6. 総括}

本研究で得られた知見を以下に整理する。

(1) 事業終了年度が未決定の事業では、設置場所を設定せずに事業が 進められる傾向があり、この点において改善の余地が見られる。ま た、設置空間の景観を考慮した設置を行う場合、事業継続年数は長 くなる傾向にあり、良好な設置環境の創造や普及活動の観点から考 えると、住民一の意向調査は必要であると考えられる。

（2）現在の屋外彫刻設置事業は、都市デザインと制作者意向を含む
【彫刻設置のコンセプト】を表現する因子と、合意形成と行政主導 を含む【設置空間検討プロセス】を表現する因子で説明することが 出来る。これは、設置に関して、制作者意向と都市デザインのコン セプトが相反するということを意味している。

（3）現在の屋外彫刻設置事業は、都市デザイン型、住民合意形成型、 行政主導型、制作者意向重視型の 4 タイプに分類することが出来る。 (4) 彫刻を既成市街地内に設置する際の知見としては、下記の 3 つ の知見が得られた。

(1)彫刻設置空間には、事業の特徵の違いにより、景観の基本的構成 に異なる特徴が見られる。

(2)事業の目的により、彫刻設置空間の特徵が異なる。まちづくりを 目的とした場合、彫刻設置空間全体が一体感や独自性をもつ空間 となり、景観形成を目的とした場合、可視領域の連続による回遊 性が生み出されている。

(3)事業プロセスの違いにより、彫刻設置空間の特徵が異なる。意向 調查を行っている場合、滞留性のある場所に設置され、設置場所 を考慮した彫刻を制作、設置した場合、望ましいと考えられる仰 角で可視である視点場が多く存在するという事が明らかになった。

注

注 1) 本研究で対象としている屋外彫刻とは、屋外に設置された自立してい るオブジェ全般を指し、建築等と一体化しているものや、壁面の装飾 は除く。また、彫像のみではなくパブリックアートと呼ばれるオブジ ェも含んでおり、誰もが容易に見ることが出来る場所に設置されてい るものとする。

注 2) 仰角・俯角の計測には、人の視点の高さを地表面 $(\mathrm{G} \mathrm{L})$ から $1.5 \mathrm{~m}$ の位 置とし、彫刻の高さから視点の高さを引いたものを視点場から彫刻中 心点までの距離で除して算出した。視点場の範囲は、壁際と彫刻端部 から $500 \mathrm{~mm}$ の地点の範囲とし、歩道上に視点場がある場合、歩道端部 にあるブロックの端と同じ位置までを視点場の範囲とした。 
注 3）既往の研究により提唱されている意味のある仰角・俯角をまとめると 下記の通りである。

\begin{tabular}{|c|c|c|}
\hline \multicolumn{2}{|c|}{ 視角 } & 対象の見え方 \\
\hline \multirow{8}{*}{$\begin{array}{l}\text { 仰 } \\
\text { 角 }\end{array}$} & & 向かいの全面が目に入る \\
\hline & $45^{\circ}$ & 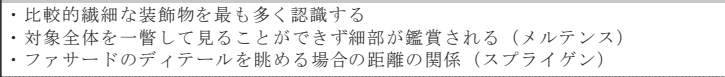 \\
\hline & & 建物全体の形を瞬時に認識できる \\
\hline & $27^{\circ}$ & 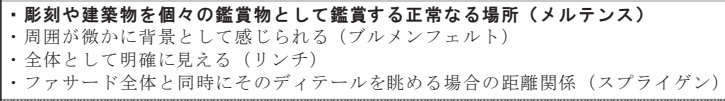 \\
\hline & \multirow[b]{2}{*}{ 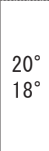 } & 普通の視野全体を占め、建築は一群として認識される \\
\hline & & 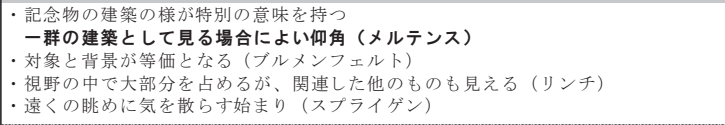 \\
\hline & & 普通の視野全体を占め、建築は一群として認識される \\
\hline & $9^{\circ}$ & 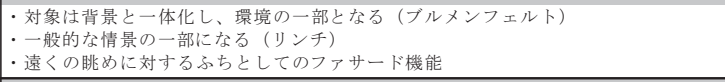 \\
\hline \multirow{2}{*}{ 俯 } & \multirow[b]{2}{*}{$10^{\circ}$} & 自然な視線の角度 \\
\hline & & $\begin{array}{l}\text { - 直立した人間の標準的な視線方向（ヘンリードレイフュス） } \\
\text { - 人間にとっ見やす領或（樋ロ） }\end{array}$ \\
\hline
\end{tabular}

注 4）本研究における視点場とは、誰もが安全かつ容易に彫刻を鑑賞できる 場所と定義する。従って、歩道上やオープンスペース、広場などが視 点場となり、車道上は視点場として設定していない。

注 5）既往の研究により得られている空間のプロポーション（D/H）について の知見をまとめると下記の通りである。

\begin{tabular}{|c|c|c|}
\hline $\mathrm{D} / \mathrm{H}$ & 空間イメージ & 空間の閉鎖感 \\
\hline 1 & 良い広場のD/H & $\begin{array}{l}\text { 高さと空間のほど良いつり合い } \\
\text { ·建築の高さとの間隔の間に、ある均整が存在する } \\
\text { (芦原) } \\
\text { ·完全な盲い (スプライゲン) }\end{array}$ \\
\hline 2 & $\uparrow_{\text {快適な } \mathrm{D} / \mathrm{H}}^{(シ ゙ ッ テ) ~}$ & $\begin{array}{l}\text { 囲われている感じはあるが広々としている } \\
\text { ·離れた、広々とした感じ（芦原） } \\
\text { ·囲いの始まり（スブライゲン） }\end{array}$ \\
\hline 3 & (リンチ) & $\begin{array}{l}\text { 囲われているというょり場所の境界となる } \\
\text { 最小限の囲い(スプライグン) } \\
\text { 竝体的に囲まれているというより、場所の境界となる }\end{array}$ \\
\hline 4 & $\underset{\leftarrow D \rightarrow}{\leftarrow}$ & \begin{tabular}{|l} 
囲いの消失 \\
·閉銷性の減少(リンチ) \\
·囲い消失(スプライゲン) \\
·囲い庭·広場のD/Hの上限
\end{tabular} \\
\hline
\end{tabular}

\section{参考文献}

1) 竹田直樹：日本の彫刻設置事業 モニュメントとパブリックアート，公人 の友社, 1997

2) 竹田直樹：都市環境における彫刻の導入手法, 千葉大学大学院 博士論 文, 1992

3) 竹田直樹、沈悦、斉藤庸平 : 公的空間における彫刻選定システムについて, 日本造園学会・ランドスケープ研究 63,pp. 675-678,2000

4) 八木健太郎、竹田直樹 : 2 つのアートプロジェクトの比較検討による都市 空間と美術作品の関係性に関する考察, 日本造園学会・ランドスケープ研究 64, pp. 835-838, 2001

5) 八木健太郎、竹田直樹 : 彫刻シンポジウムにおけるコラボレーションによ る公共空間デザインに関する考察, 日本造園学会・ランドスケープ研究 65 (5), pp. 869-874, 2002

6) 高橋一穂、小林英嗣、小篠隆生、宮脇勝 : 都市の公共空間形成に関寸る研 究 (1), 日本建築学会大会学術講演梗概集 F-1, pp. 465-466, 1999

7) 西田武人、小林英嗣、小篠隆生、宮脇勝 : 都市の公共空間形成に関する研 究 (2)，日本建築学会大会学術講演梗概集 F-1, pp.463-464， 1999

8) 長谷尚希、志水英樹、越田益生 : 屋外彫刻が都市空間に及ぼす影響に関す る研究, 日本建築学会大会学術講演梗概集 F-1, pp. 207-208, 1997

9) 堀江邦英、志水英樹、越田益生、菊池志保美 : 屋外彫刻のある都市空間の 評価構造〜背景の広がりによる変化〜, 日本建築学会大会学術講演梗概集 F-1, pp. 735-736, 1998

10) 堀江邦英、志水英樹、越田益生、長谷尚希 : 屋外彫刻が都市空間に及ぼす 影響 その 1 , 日本建築学会大会学術講演梗概集 F-1, pp. 467-468, 1999
11) 長谷尚希、志水英樹、越田益生、堀江邦英 : 屋外彫刻が都市空間に及ぼす 影響 その 2 , 日本建築学会大会学術講演梗概集 F-1, pp. 469-470, 1999

12) 上本裕保、堀越哲美 : パブリックアート作品設置における住民参加方法に ついての実践的研究, 日本建築学会大会学術講演梗概集 F-1, pp. 739-740, 1998

13) 上本裕保、堀越哲美、茂登山清文、川村聖治 : パブリックアート設置にお けるコーディネートの役割についての実践的研究, 日本建築学会大会学術 講演梗概集 F-1, pp. 473-474, 1999

14) 木村光宏、北川フラム : <都市・パブリックアートの新世紀>ファーレ立 川アートプロジェクト, 現代企画室, 1995

15) $\mathrm{M} ・ \mathrm{~A} ・$ ロビネット著、千葉成夫訳: 屋外彫刻 [オブジェと環境] SD 選書 192, 鹿島出版会, 1985

16) MATSU0, M. and IKARUGA, S. : Evaluation of the Sculpture Installation in the Urban Space through Visual Characteristics、 The 5th International Symposium on City Planning and Environmental Management in Asian Countries, pp. 43-54、2006

17) YAMAMOTO. Y. and IKARUGA. S., KOBAYASHI. T. : The Open-Air Sculpture Installation to Improve Cityscape、The 6th International Symposium on City Planning and Environmental Management in Asian Countries pp. 93-102、2008

18) 山本有希子、鵤心治 : バルセロナ市街地における屋外彫刻設置空間に関す る研究, 日本建築学会大会学術講演梗概集 F-1, pp. 981-982, 2008

19) 山本有希子、鵤心治: 都市景観形成のための屋外彫刻設置に関寸る研究 そ の 1 , 日本建築学会大会学術講演梗概集 F-1, pp. 23-24, 2007

20) 矢部浩靖、山本有希子、鵤心治: 都市景観形成のための屋外彫刻設置に関 する研究 その 2 , 日本建築学会大会学術講演梗概集 F-1, pp. 25-26, 2007

21)福井市 : 福井市彫刻のある街づくり基本計画・1990, 1990

22) 金沢市：金沢まちなか彫刻設置基本方針, 2005

23) 長野市：ながの野外彫刻ガイドブック, 2006

24) 河内長野市緑化公園課、(侏三貴・景設計事務所 : 彫刻とみどりのまちづく り・基本計画書, 1992

25)宇部市 : 宇部の彫刻ガイド, 1997

26) 宇部市教育委員会文化振興係：彫刻散歩道一宇部市全域〜市街地コース 一, 2003

27)樋口忠彦 : 景観の構造, 技報堂出版株式会社, 1975

28) 槇文彦 : 見えがくれする都市 SD 選書 162, 鹿島出版会, 1980

29) 鳴海邦碩、田端修、榊原和彦 : 都市デザインの手法, 学芸出版社, 1990

30 ) 社団法人 日本建築学会（代表者仙田満）：第 2 版コンパクト建築設計資 料集成, 丸善株式会社, 1994

31)芦原義信 : 街並みの美学, 岩波書店, 2001

32)芦原義信 : 続・街並办の美学, 岩波書店, 2001

33)ケビン・リンチ: 都市のイメージ,岩波書店, 1968

34) カミロ・ジッテ：広場の造形 SD 選書 175, 鹿島出版会, 1983

35) ポール・D・スプライゲン：アーバンデザイン，青銅社, 1966

（2009年 7 月 7 日原稿受理， 2010年 4 月 1 日採用決定） 